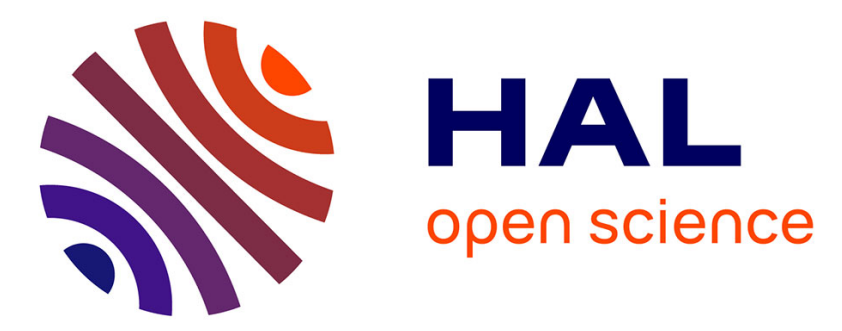

\title{
The impact of water and sanitation access on housing values: The case of Dapaong, Togo
}

Johanna Choumert, Eric Nazindigouba Kere, Amandine Loyal Laré-Dondarini

\section{To cite this version:}

Johanna Choumert, Eric Nazindigouba Kere, Amandine Loyal Laré-Dondarini. The impact of water and sanitation access on housing values: The case of Dapaong, Togo. 2015. halshs-00939267v2

\section{HAL Id: halshs-00939267 \\ https://shs.hal.science/halshs-00939267v2}

Preprint submitted on 5 Jun 2015

HAL is a multi-disciplinary open access archive for the deposit and dissemination of scientific research documents, whether they are published or not. The documents may come from teaching and research institutions in France or abroad, or from public or private research centers.
L'archive ouverte pluridisciplinaire HAL, est destinée au dépôt et à la diffusion de documents scientifiques de niveau recherche, publiés ou non, émanant des établissements d'enseignement et de recherche français ou étrangers, des laboratoires publics ou privés. 


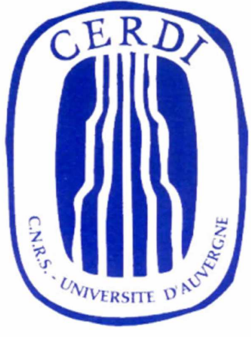

CENTRE D'ETUDES

ET DE RECHERCHES

SUR LE DEVELOPPEMENT

INTERNATIONAL

\section{SERIE ETUDES ET DOCUMENTS DU CERDI}

The impact of water and sanitation access on housing values:

The case of Dapaong, Togo

Johanna CHOUMERT, Eric N. KERE, and Amandine Loyal LARÉ

Etudes et Documents $\mathrm{n}^{\circ} 03$

January 2014 


\section{The authors}

Johanna Choumert, Clermont Université, Université d'Auvergne, CNRS, UMR 6587, CERDI, F63009 Clermont Fd

Email: johanna.choumert@udamail.fr

Eric N. KERE, Clermont Université, Université d'Auvergne, CNRS, UMR 6587, CERDI, F-63009

Clermont Fd

Email : kereneric@yahoo.fr

Amandine Loyal LARÉ, CREAM - University of Rouen, 3, avenue Pasteur, 76186 Rouen Cedex 1, France

Email: loyallare@gmail.com

This work was supported by the LABEX IDGM+ (ANR-10-LABX-14-01) within the program "Investissements d'Avenir" operated by the French National Research Agency (ANR)

La série des Etudes et Documents du CERDI est consultable sur le site : http://www.cerdi.org/ed

Directeur de la publication : Vianney Dequiedt

Directeur de la rédaction : Catherine Araujo Bonjean

Responsable d'édition : Annie Cohade

ISSN : $2114-7957$

\section{Avertissement :}

Les commentaires et analyses développés n'engagent que leurs auteurs qui restent seuls responsables des erreurs et insuffisances. 


\section{Abstract}

The international community has made a commitment that aims to halve, by 2015 , the number of people without access to safe drinking water and hygienic sanitation systems. In Togo, the government struggles to provide the population with access to water and sanitation, despite a proactive policy. We argue that a connection to safe water and sanitation increases housing values. Using collected data from the city of Dapaong, we develop a hedonic price model to capture the relationship between housing values and their characteristics. Our results support the need to accompany any investment in access to water and sanitation with real estate policies, so that the poorest households remain beneficiaries of the pro-poor policies.

\section{Keywords}

Africa, latrines, Millennium Development Goals, hedonic price, multi-level model, variance components model

\section{JEL Codes}

N57, O18, 02, R21, Q25 


\section{Introduction}

While the international community has begun discussions on the passage from the Millennium Development Goals (MDGs) to Sustainable Development Goals (SDGs) to prepare for the post-2015 phase, access to safe water and adequate sanitation remains important in the fight against poverty. Indeed, the absence or inadequacy of drinking water and sanitation affects the living standards of the populations concerned (Hutton et al., 2007; Kayaga et al., 2003). According to the World Health Organization (WHO), "88\% of diarrhoeal disease is attributed to unsafe water supply, inadequate sanitation, and hygiene." ${ }^{1}$ UNICEF reports that 7 million people worldwide, including at least 2 million children under 5 , die each year from water-related diseases. To solve this problem, the international community has thus made a commitment that aims to halve, by 2015 , the number of people without access to safe drinking water and hygienic sanitation systems (MDGs).

In achieving the MDGs, Sub-Saharan Africa lags behind the rest of developing and transition countries. The countries in this region face enormous difficulties in terms of allowing their population access to drinking water and to basic sanitation systems. As with all other countries in the subcontinent, Togo will struggle to reach the MDGs by 2015. Indeed, today only $40 \%$ of the population has access to improved water and, worse still, in 2010 only $13 \%$ of the population had access to improved sanitation facilities in the sense of the MDGs $\left(J M P,{ }^{2} 2012^{3}\right.$ ). These cover public sewer connections, septic system connections, pour-flush latrines, simple pit latrines, and ventilated improved pit latrines. ${ }^{4}$

The Togolese government struggles to provide the majority of the population with access to improved water and sanitation, despite a proactive policy in the water sector. Indeed, this sector requires huge investments. Thus, the government needs the support of international development actors, as it hopes to achieve the target by 2015.

The issue of wide access to improved water and sanitation is greater in Africa especially in the context of rapid urbanization and constant urban extension of cities. According to the United Nations Fund for Population Activities (UNFPA, 2007), the urban population in Africa will double from 2000 to 2030. This poses enormous problems of access to housing for the growing urban population. There is indeed a mismatch between increasing demand for housing and insufficient supply, with the consequent lack of common utilities, and various urban infrastructures such as access to water and sanitation. In this context, it is essential to analyze the formation of housing values and to determine how basic services, such as access to safe water and sanitation, are capitalized into these values. Beyond the fact that such information is essential for utility managers in low-income countries, studying these interactions is important for two reasons.

\footnotetext{
1 Source: http://www.who.int/water_sanitation_health/publications/factsfigures04/en/, last consulted 28/01/2013

${ }^{2}$ JMP is in charge of the follow-up on the progress and achievement of the MDGs from the point of view of water supply and sanitation.

${ }^{3}$ Source: http://www.wssinfo.org/data-estimates/introduction/, last consulted on 06/10/2013

${ }^{4}$ The WHO/UNICEF Joint Monitoring Program (JMP) distinguishes four types of sanitation, mainly grouped into two big categories: "improved" versus "non-improved". Among the non-improved systems is defecation in nature (which in fact corresponds to the lack of latrine) and the traditional latrines that includes all the nonhygienic facilities (non-built pits, lack of ventilation system, use of non-perennial materials, and so forth) that bear risks for health and the environment. Among the "improved" facilities, one can distinguish the ventilated improved pit latrines, the manual flush toilets, the ecologic latrines such as "Ecosan," and also the modern flush toilets (modern toilets).
} 
First, increasing attention has been given to Water, Sanitation, and Hygiene ("WASH", as this is called in international development programs) access due to its status in poverty reduction policies and MDGs. Recent developments in the literature put forward the considerable cost of extending the water network (Nauges and Van Den Berg, 2009; Onjala et al., 2013; and Stage and Uwera, 2012). As pointed out by Stage and Uwera (2012), in poorer countries, massive water investment programs are still a long way off. What is more, if new connections are established, it may be required that households pay the entire investment costs. For liquidity-constrained households, such expenditure is unrealistic. A way to secure a water connection and sanitation is to buy or rent a property that is already connected to these basic services. As a consequence, one may expect the real estate market to reflect the value of water and sanitation access. Hence, this is a research imperative that calls for considerable efforts towards understanding households' willingness-to-pay for water and sanitation and, in fine, carries policy implications.

Second, the hedonic pricing method (HPM) has drawn attention from scholars for several decades since the seminal paper by Rosen (1974). Studying real estate markets in African cities may therefore offer an interesting case for understanding the impacts of infrastructure and utilities investments on households. It should be noted that research on the interactions between amenities and real estate markets in African cities is scarce, although, as explained above, the stakes are high. Existing studies in African cities (Arimah, 1992; Asabere, 1981a; Asabere, 1981b; Asabere, 2004; Choumert et al., 2013; Els and Von Fintel, 2010; Gulyani and Talukdar, 2008; Knight et al., 2004; and Megbolugbe, 1989) find contrasting results. To our knowledge, no hedonic study has been performed on the Togolese housing market.

In this paper, we estimate the costs incurred by households to access certain housing characteristics, i.e. their implicit marginal price, in the city of Dapaong in Togo. Precisely, we focus on access to water and sanitation. The structure of this paper is as follows. Section 2 presents issues in the access to property in Togo. Section 3 discusses the literature on the use of the hedonic price method applied to water and sanitation in the African context. Data collection is presented in Section 4. Section 5 covers the empirical strategy. Results and policy implications are discussed in Section 6 before we conclude.

\section{Access to housing in Togo}

The UN set the MDGs to be achieved by 2015 . This global initiative has eight goals, consisting of 17 targets broken down into 48 indicators. Togo, as well as other developing countries, undertook to achieve the MDGs, notably in matters of water and sanitation. However, the conjunction of the long socio-political turmoil since 1991 and the world food and financial crises of 2008 and 2009 have heavily penalized the country (UNDP, 2010). In 2010, 51\% of the population carried on defecating in nature and only $6 \%$ have piped water (JMP WHO/UNICEF, 2012). ${ }^{5}$

Access to land is one of the concerns of the population, thereby driving the expansion of cities and the increasing development of land and real estate markets (Houdeingar, 2009). Before colonization, customary tenure prevailed. ${ }^{6}$ Colonization brought a modern regime founded on the notion of private property as defined by the French Civil Code. It is a regulation regime written with

\footnotetext{
${ }^{5}$ http://www.wssinfo.org/

${ }^{6}$ It is an unwritten tenure in which land ownership is collective. Actually the property law was basically grounded on the right of the first occupier, gift, heritage, or exchange.
} 
the concept of private property leading to "definite and unassailable land ownership." Today, these two systems coexist in Togo (Houdeingar, 2009), which translates into 3 modes of access to land: (i) acquisition by operating lifetime, which is older and characterized by the recognition of the right to land in a community who practiced farming and/or grazing continuously for at least three generations, that is to say 75 years without an area disputed by a third party; (ii) acquisition by legate, that is to receive the gift of the land area, which generally relates to foreigners who have lived long in the area and who had to render important services to the community; and (iii) acquisition by purchase, which is concretely the exchange of goods-land ownership against payment.

Several texts govern the organization of land in Togo ${ }^{7}$ and three Government departments are in charge of land ownership matters: Town Planning and Housing Department (with a section in charge of the conception of national and regional development); Agriculture, Breeding, and Fishery Department (whose section of development and equipment is in charge of the management of rural lands); and Finance and Economy Department (which, through the office for land ownership and cadastral, plays an important role in the management of Togo's national land heritage).

The different stages of homeownership (land or plot) in Togo are as follows: (i) the customer gets a receipt for the purchase; (ii) the layout is drawn up by a registered surveyor and signed by the Town Planning Department (for land in an urban area) or the development and equipment office (for land in a rural area) and the cadastral; (iii) confirmation of the sale by means of either a lawyer (in order to establish a notarized certificate confirming the sale), a decision to confirm the sale or the establishment of a sale contract by the city council, or the prefecture; (iv) registration and publication in the official announcements by the office of home ownership and cadastral; (v) contradictory boundary marking by the cadastral; and (vi) officially granting land ownership to the purchaser that becomes the owner of the land. That land ownership is unassailable and imprescriptible.

Togo's real estate market is segmented. Indeed, the properties are highly heterogeneous. The main types of housing are celibatoriums, villas, mud houses, and huts.

Informal settlements occupy a growing portion of the urban space in the context of urban sprawl. The inhabitants of the shantytowns are considered, at first glance, as the city's poorest. Note that poverty is not confined to poor outlying neighborhoods. The poor are scattered in many districts. They may be migrants recently arrived in town or unemployed youth, etc. The low capacity of mobility in these expanding urban spaces is a component of poverty (Bertrand, 2011). It particularly relates to tenants who are unable to rent better housing in another neighborhood or who cannot meet the resources necessary to buy land and build a house in the new extensions of the city. The poor are also the individuals who live in the periphery and cannot afford the cost and time implied by increased commuting to activities in areas located in central districts. This dissemination of the poor in urban areas is related to the increasing deterioration of working conditions and employment since the 1980s, in the context of structural adjustment policies. The wage crisis in the modern sector has gone hand-in-hand with an increase in low-paid informal activities.

${ }^{7}$ (i) The 24 July 1906 decree about the management of the land ownership regime in the colonies and territories dependent on the General Government of French West Africa; (ii) law n 60/26 of 5 August 1960 about the protection of land ownership for Togolese citizens; (iii) decree n 66-186 of 29 October 1966 amending some articles of the 24 July 1906 land ownership decree; (iv) order n 12 of 6 February 1974 setting the land ownership regime; $(v)$ decree $n$ 85-02 of 10 January 1985 creating, attributing and organization of the general office of taxation (with the office for land ownership and cadastral being linked to the general office for taxation); (vi) decree n 90-32 of 23 March 1990 creating a new interdepartmental committee for land ownership reform. 


\section{Literature review}

Two major issues emerge when studying water and sanitation. On the one hand, there is the question of household's preferences and their willingness-to-pay and, on the other hand, financing such services.

The literature on the topic of access to drinking water and sanitation in developing countries is abundant. Generally, these studies examine the willingness-to-pay (WTP) for improved water services (ex-ante studies), the determinants of choices (ex-ante), or the determinants of actual choice (ex-post) of the mode of household supply, and finally, the demand for safe drinking water. Authors generally start from a collection of data obtained through household surveys, then they analyze the demand or the determinants of household choices in water access (see, for instance, Ahmad et al., 2005; Briand et al., 2009a; Briand et al., 2009b; Briand and Laré, 2013; Nauges and Strand, 2007; and Nauges and Whittington, 2009). Others analyze what motivates attitudes and preferences in terms of latrines and sanitation (Jenkins and Curtis, 2005; Whittington et al., 1993, 2012)

Another approach is the use of the hedonic pricing method (HPM) (Rosen, 1974). It has seen important development in the field of environmental and natural resources economics because of its ability to measure, from observed behaviors, values that households allocate to various amenities. From the perspective of public policy, this method provides an overview of the functioning of residential markets and of the implicit prices of amenities. The HPM has drawn attention from scholars for several decades but not in African countries, probably due to the lack of real estate data.

Yet the African city will undoubtedly be at the heart of large questions about the interactions between urbanization, housing, access to infrastructure and amenities-crucial issues from the perspective of the transition from Millennium Development Goals (MDGs) to Sustainable Development Goals (SDGs).

Few hedonic pricing studies have been carried out on African real estate markets. Research is even scarcer regarding water and sanitation, and results are mixed. Asabere (1981) and Asabere (2004) analyze housing values in Ghana and find significant impact from access to a package of services that include piped water. However, access to water is not studied separately. Megbolugbe (1989) investigates assessed property values in Jos, Nigeria and finds that access to water matters for the valuation of single-household dwellings but not for multi-household dwellings. Arimah (1992) does not find a significant impact of access to piped water or of having a water-operated lavatory when analyzing the rental housing in Ibadan (Nigeria). Knight et al. (2004) study rental prices in Uganda. They find a positive effect of piped water and flush toilets on rents. Gulyani and Talukdar (2008) find that access to piped water and "reasonable access to toilet" ${ }^{8}$ are determinants of monthly rent in Nairobi slum areas in Kenya. In a study on sale prices in South Africa, Els and Von Fintel (2010) find that the number of bathrooms does matter. Finally, Choumert et al. (2013) find a positive impact of piped water access on rental values in Kigali, Rwanda.

\footnotetext{
8 "Defined as those where the renter shares a toilet facility with less than ten households."
} 
It is therefore difficult to draw conclusions from this still embryonic literature. ${ }^{9}$ Whether access to piped water and sanitation has an impact on real estate price (and to what extent) remains an open question.

\section{Data collection}

\subsection{Dapaong city}

Dapaong city in Northern Togo (a French speaking country), is in the constituency of Tone, in the Savannah region (the poorest region of the country). With an area of 115 square $\mathrm{km}$, it is $650 \mathrm{~km}$ away from Lomé, the capital city of Togo, and $300 \mathrm{~km}$ from Ouagadougou, the capital city of Burkina Faso. The weather is Sahelian tropical with a long dry season that heavily influences agriculture.

The city of Dapaong is divided into 26 districts and its population is estimated at 68,650 inhabitants (Direction Régionale de la Statistique, 2010).

\subsection{Investigation and data collected}

The household survey was conducted in 2010 from April to June by five investigators. ${ }^{10}$ The questionnaire was conceived in order to collect data on the socio-economic characteristics of the households of different areas of Dapaong city, their current mode of access to water and sanitation, and also their hygienic and health practices. In order to have a representative sample of the population, we have used a simple stratified random survey (see appendix A for more details on the survey). The city has thus been divided into four sub-groups regarding the geographical situation and the coverage of the TDE ${ }^{11}$ network. Then, households were randomly drawn in each of the four groups. Data collection was conducted on a sample of 556 households in the 26 districts, including 86 households in the peripheral area, 169 in the Center West, 107 in the Center East, and 196 in the Center (cf. Figure 1). Among these households, 386 are owners (278 own dwellings in celibatoriums, 108 in mud houses), while the rest rent their dwellings or are accommodated free of charge. The average monthly income of these 386 households is Fcfa 69,825 .

\footnotetext{
${ }^{9}$ There exist, however, hedonic studies for the valuation of access to water in other developing country contexts, e.g. in Latin America (de Oca et al., 2003; Nauges et al., 2008) and in Asia (Anselin, 2008; North and Griffin, 1993; van den Berg and Nauges, 2012; and Yusuf and Koundouri, 2004).

${ }^{10}$ The questionnaire was administered before the start of a project of the NGO EAST (Eau Agriculture Santé en Milieu Tropical) funded by the SEDIF (Syndicat des Eaux d'lle de France) and the city of Issy-Les-Moulineaux (France). The purpose was to study a front project for the extension of the public water network by the TDE (Togolaise des Eaux, the public company for water supply in Togo), and the promoting of family and public latrines.

${ }^{11}$ Togolaise des Eaux: public company for water supply in Togo
} 
Figure 1. The city of Dapaong

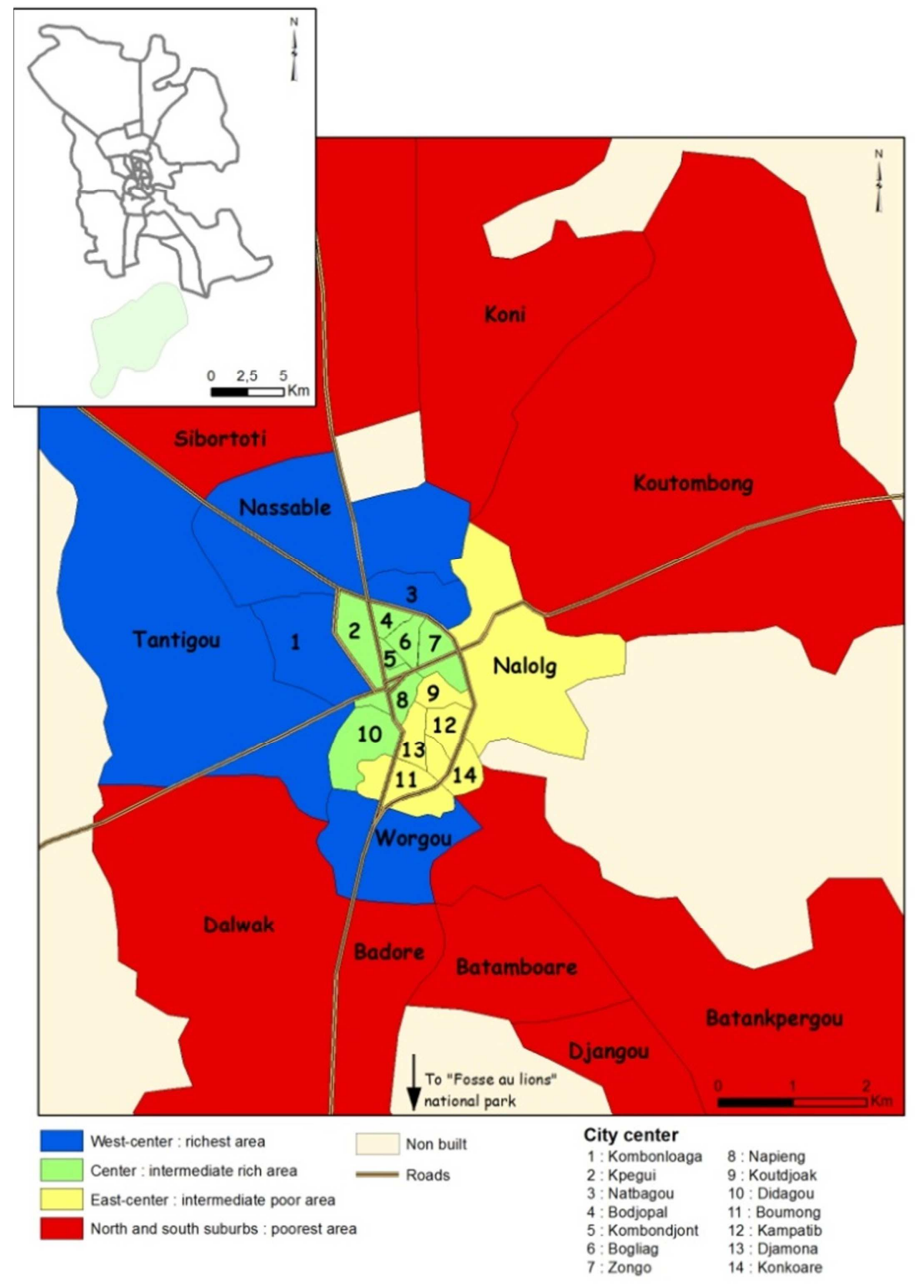

\section{Empirical analysis}

\section{a. Variables}

The dataset includes 386 houses units, among which 108 are "mud houses" and 278 are "celibatoriums." A mud house is a structure characteristically built of banco (adobe or mud brick). A celibatorium is composed of several housing units (while being different from an apartment building). For each, we have the estimated value given by the household (Housing_value) and intrinsic characteristics: the number of rooms ${ }^{12}$ (Room), the construction material of walls (e.g. in cement Cement_wall as opposed to adobe Adobe_wall and improved adobe walls Adobe2_wall), the construction material of the floor (e.g. in cement Cement floor as opposed to sand Sand floor and clay Clay floor), the state of the dwelling (Excellent, Medium, Degraded, Unfinished), and access to

\footnotetext{
${ }^{12}$ Considered as a room: bedrooms, living rooms (Excluded: bathrooms, kitchens, and toilets).
} 
electricity (Elec). Finally, we include a variable for access to piped water within the dwelling (Piped_water) and one for the presence of latrines in the MDGs' sense (Latrine_MDG). ${ }^{13}$

Descriptive statistics of variables are provided in Tables 1 and 2. Appendix B provides statistics for the full sample.

Table 1 - Descriptive statistics for celibatoriums

\begin{tabular}{lcccc}
\hline & mean & sd & min & max \\
\hline Housing_value & 5172823.741 & 5209992.76 & 300000 & 35000000 \\
InHousing_value & 15.148 & 0.76 & 12.6 & 17 \\
\hline Room & 8.773 & 5.02 & 2.0 & 37 \\
InRoom & 2.034 & 0.52 & 0.7 & 4 \\
\hline Cement_wall & 0.845 & 0.36 & 0 & 1 \\
Adobe_wall & 0.115 & 0.32 & 0 & 1 \\
Adobe2_wall & 0.036 & 0.19 & 0 & 1 \\
\hline Cement_floor & 0.964 & 0.19 & 0 & 1 \\
Sand_floor & 0.018 & 0.13 & 0 & 1 \\
Clay_floor & 0.018 & 0.13 & 0 & 1 \\
\hline Medium & 0.507 & 0.50 & 0 & 1 \\
Degraded & 0.183 & 0.39 & 0 & 1 \\
Unfinished & 0.212 & 0.41 & 0 & 1 \\
Excellent & 0.090 & 0.29 & 0 & 1 \\
\hline Elec & 0.540 & 0.50 & 0 & 1 \\
\hline Piped_water & 0.076 & 0.26 & 0 & 1 \\
\hline Latrine_MDG & 0.199 & 0.40 & 0 & 1 \\
\hline Latrine_VIP & 0.112 & 0.32 & 0 & 1 \\
Latrine_Ecosan & 0.014 & 0.12 & 0 & 1 \\
Latrine_TMC & 0.061 & 0.24 & 0 & 1 \\
Latrine_Modern & 0.011 & 0.10 & 0 & 1 \\
Latrine_Public & 0.025 & 0.16 & 0 & 1 \\
Latrine_Traditional & 0.493 & 0.50 & 0 & 1 \\
Latrine_Nature & 0.281 & 0.45 & 0 & 1 \\
\hline$N$ & 278 & & & \\
\hline & & & & \\
\hline
\end{tabular}

Table 2 - Descriptive statistics for mud houses

\begin{tabular}{lcccc}
\hline & mean & sd & min & max \\
\hline Housing_value & 3170370.37 & 4325749.01 & 350000 & 40000000 \\
InHousing_value & 14.566 & 0.84 & 12.8 & 18 \\
\hline Room & 7.259 & 4.13 & 2 & 23 \\
InRoom & 1.845 & 0.52 & 0.7 & 3 \\
\hline Cement_wall & 0.046 & 0.21 & 0 & 1 \\
Adobe_wall & 0.815 & 0.39 & 0 & 1 \\
Adobe2_wall & 0.139 & 0.35 & 0 & 1 \\
\hline Cement_floor & 0.889 & 0.32 & 0 & 1 \\
Sand_floor & 0.019 & 0.14 & 0 & 1
\end{tabular}

\footnotetext{
${ }^{13}$ Latrine_MDG is the sum of Latrine_VIP, Latrine_Ecosan, Latrine_TMC, and Latrine_Modern.
} 


\begin{tabular}{lcclc} 
Clay_floor & 0.093 & 0.29 & 0 & 1 \\
\hline Medium & 0.278 & 0.45 & 0 & 1 \\
Degraded & 0.630 & 0.49 & 0 & 1 \\
Unfinished & 0.083 & 0.28 & 0 & 1 \\
\hline Elec & 0.194 & 0.40 & 0 & 1 \\
\hline Piped_water & 0.009 & 0.10 & 0 & 1 \\
\hline Latrine_MDG & 0.037 & 0.19 & 0 & 1 \\
\hline Latrine_VIP & 0.009 & 0.10 & 0 & 1 \\
Latrine_TMC & 0.028 & 0.17 & 0 & 1 \\
Latrine_Public & 0.028 & 0.17 & 0 & 1 \\
Latrine_Traditional & 0.306 & 0.46 & 0 & 1 \\
Latrine_Nature & 0.630 & 0.49 & 0 & 1 \\
\hline$N$ & 108 & & &
\end{tabular}

By comparing Figures 1 and 2, it appears that the districts where average house prices are the most expensive are the central ones: old town, with better access to services (water, electricity, etc.). These areas include most of the rich people. Conversely, neighborhoods where the lowest average house prices are observed concentrate less rich populations in our sample.

Figure 2. Average value of homes based on districts

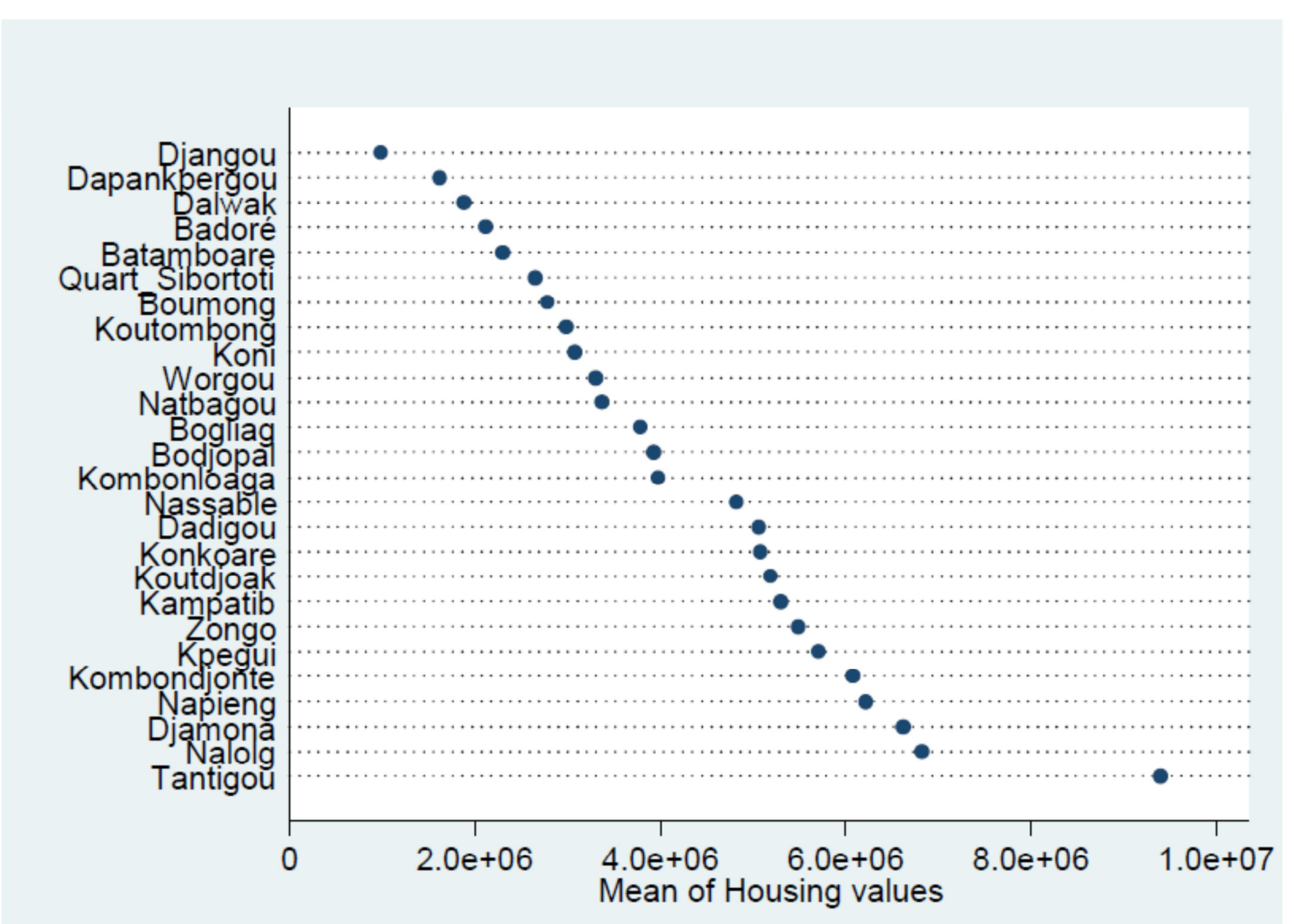




\section{b. Fixed effects models versus random effects models}

According to Jones and Bullen (1994) and Orford (2000) the hedonic price function applied to the housing market can be written as follows:

$$
P_{i}=\beta_{0}+\sum_{k=1}^{K} \beta_{k} X_{k i}+\varepsilon_{i}
$$

where: $i=1, \ldots, \mathrm{N} ; P_{i}$ : price of the housing; $X_{k i}$ : attributes of the housing; and $\varepsilon_{i} \sim N\left(0, \sigma_{\varepsilon}^{2}\right):$ the random error term.

The City of Dapaong is divided into 26 districts. To take into account the effect of belonging to a neighborhood, we can use either a fixed effects model or a random effects model. In the fixed effects models, belonging to a neighborhood is taken into account by a dummy variable equal to 1 for residents of the district and 0 otherwise, such that:

$$
P_{i}=\beta_{0}+\sum_{k=1}^{K} \beta_{k} X_{k i}+\sum_{j=1}^{J-1} \alpha_{j} Q_{i j}+\varepsilon_{i}
$$

where $j=1, \ldots, \mathrm{J}$ designates the district where the owner lives and $\alpha_{j}$ the fixed effect linked to belonging to district $j$.

According to Jones (1991), this model assumes that "all the relevant variation is at one scale, that there is no auto-correlation, and that there is a single general relationship across space and time ... $[T]$ his model denies geography and history; everywhere and anytime is basically the same."

The random effects model, also called variance components model or multi-level model, allows us to take into account the spatial correlation of house prices in the inner districts (Jones, 1991; Jones and Bullen, 1994; and Orford, 2000). In this case, the hedonic price function is written as follows:

$$
P_{i j}=\beta_{0 j}+\sum_{k=1}^{K} \beta_{k} X_{k i}+\varepsilon_{i}
$$

With $\beta_{0 j}=\beta_{0}+u_{j}$ and $u_{j} \sim N\left(0, \sigma_{u}^{2}\right)$ the same random effect for all the houses in the same district, it can capture the effect of context related to membership in a neighborhood.

In this study, the random effects model is more appropriate. Indeed, according to the localization of districts (proximity to the city center) and amenities that are present (markets, schools, etc.), quality of life will be different from one area to another. In fact, as can be seen in Figure 2, house prices tend to be generally higher in areas where the quality of life is high. Home prices vary, therefore, at two distinct geographical levels: individual (home) and neighborhood. Furthermore, according to Orford (2000), "inferential errors are likely to occur when inappropriate single-level models are used, and when multilevel data are modelled using techniques designed for a random sample, such as OLS regression. These problems can be overcome by specifying the model, not as varying at a single level, but as varying simultaneously over a number of levels."

The model to be estimated can be written in the following reduced form:

$$
P_{i j}=\beta_{0}+u_{j}+\sum_{k=1}^{K} \beta_{k} X_{k i}+\varepsilon_{i}
$$

\section{c. Test for a selection problem}


The database includes 386 housings, of which 108 are "mud houses" and 278 are "celibatoriums." By their nature--the materials used and the cost of construction--celibatoriums and mud houses are very different. In fact, they are very heterogeneous properties that cannot be analyzed simultaneously in the same sample. In effect, this would create a problem of heteroscedasticity. In addition, the Student's t-test for independent samples leads to rejecting the assumption of the homogeneity of these two sub-samples with a probability of 0.001 .

On average, celibatoriums are more expensive than mud houses (Fcfa 5,172,823 against Fcfa $3,170,370)$. If we consider the decision to own a mud house or celibatorium as a market decision, we will have self-selection on the part of households. The poorest would go mostly to mud houses, while the richest would opt for celibatoriums. The selection problem can be addressed by a two-regime, endogenous-switching model, allowing for the consideration of the decision to buy a mud house or a celibatorium. However, the estimation of this model reveals the absence of selection. ${ }^{14}$ We can therefore estimate, independently, a hedonic price equation for each type of home. The two equations are estimated independently.

The hedonic price function for celibatoriums is:

$$
P_{C i j}=\beta_{c 0}+u_{c j}+\sum_{k=1}^{K} \beta_{c k} X_{c k i}+\varepsilon_{c i}
$$

The hedonic price function for mud houses is:

$$
P_{m i j}=\beta_{m 0}+u_{m j}+\sum_{k=1}^{K} \beta_{m k} X_{m k i}+\varepsilon_{m i}
$$

\section{d. Estimation strategy}

We first estimate ${ }^{15}$ models without explanatory variables; this allows for the calculation of the contribution of each level (individual and district) to the total variance of house prices. We then calculate the intra-district correlation $\rho=\frac{\sigma_{u}^{2}}{\sigma_{\varepsilon}^{2}+\sigma_{u}^{2}}$. According to our results (cf. Table 3), house prices are correlated within neighborhoods of Dapaong. Depending on the specification chosen, between $3.7 \%$ and $16.6 \%$ of the total variance in celibatorium house price specification is explained by membership in a district. This percentage is higher for mud houses; it varies between $33 \%$ and $92 \%$. The high correlation between mud house prices within districts is explained by the smallness of the value of these houses compared to the value of land plots on which they are built. In fact, other things being equal, land value is highly correlated within districts.

\footnotetext{
${ }^{14}$ Tables are available upon request to the authors.

${ }^{15}$ We use the maximum likelihood estimator.
} 
Table 3. Hedonic price models without explanatory variables

\begin{tabular}{lcccc}
\hline & \multicolumn{2}{c}{ Celibatoriums } & \multicolumn{2}{c}{ Bancos } \\
\hline VARIABLES & Housing_value & InHousing_value & Housing_value & InHousing_value \\
\hline \multirow{4}{*}{$\sigma_{u}$} & $993,331^{* *}$ & $0.314^{* * *}$ & $6,920,142^{* * *}$ & $0.499^{* * *}$ \\
& $(460,206)$ & $(0.0880)$ & $(1,039,460)$ & $(0.129)$ \\
$\sigma_{\varepsilon}$ & $5,105,691^{* * *}$ & $0.711^{* * *}$ & $2,015,372^{* * *}$ & $0.700^{* * *}$ \\
& $(223,953)$ & $(0.0320)$ & $(159,969)$ & $(0.0571)$ \\
$\rho$ & 0.037 & 0.163 & 0.921 & 0.336 \\
Constant & $5,076,964^{* * *}$ & $15.09 * * *$ & $4,368,260 * * *$ & $14.63^{* * *}$ \\
& $(393,807)$ & $(0.0843)$ & $(1,377,250)$ & $(0.124)$ \\
Log likelihood & -4692.51 & -312.69 & -1769.98 & -128.70 \\
Observations & 278 & 278 & 108 & 108 \\
Number of & 24 & 24 & 26 & 26 \\
districts & & & & \\
\hline
\end{tabular}

We then estimate the full model with all explanatory variables (cf. Tables 4,5 , and 6 ). The results obtained by means of the HPM are sensitive to the functional form chosen. Its choice has been and remains the subject of many discussions ${ }^{16}$ since the seminal paper by Rosen (1974). Therefore, we estimate four models, i.e. linear, lin-log, log-lin, and log-log models. We now focus on celibatoriums, since only the number of rooms and the type of floor appear significant for mud houses.

In order to select the appropriate model, we use the J-test ${ }^{17}$ and PE-test (cf. Appendix C). Tests indicate that the log-lin model is the best specification. However, in this specification the variables Piped_Water and Latrine_MDG are not significant (although Piped_water is significant in Table 4, models $A$ and $B$ ). Therefore, we propose another estimate in which we disaggregate the latrine_MDG variable by type of latrine (cf. Table 7).

\footnotetext{
${ }^{16}$ The article by Cropper et al. (1988) is a reference article on the subject.

${ }^{17} \mathrm{~J}$-test performs the Davidson-Mackinnon J test for comparing non-nested models. Following the J-test, if the first model is correctly specified, then including the fitted values of the second model into the set of regressors should provide no significant improvement. But if it does, it can be concluded that model 1 is not correctly specified. PE-test performs the MacKinnon-White-Davidson PE test for comparing linear vs. log-linear specifications. Following the PE-test, if the linear specification is correctly specified then adding an auxiliary regressor with the difference of the log-fitted values from both models should be non-significant. Conversely, if the log-linear specification is correct, then adding an auxiliary regressor with the difference of fitted values in levels should be non-significant. (For further details, see: Davidson and MacKinnon (1981); MacKinnon, White and Davidson (1983); and Greene (2003)).
} 
Table 4. Hedonic price model for celibatoriums

\begin{tabular}{|c|c|c|c|c|}
\hline VARIABLES & $\begin{array}{l}\text { Model A } \\
\text { Lin_lin }\end{array}$ & $\begin{array}{l}\text { Model B } \\
\text { Lin_log }\end{array}$ & $\begin{array}{l}\text { Model C } \\
\text { Log_lin }\end{array}$ & $\begin{array}{l}\text { Model D } \\
\text { Log_log }\end{array}$ \\
\hline Room & $\begin{array}{c}598,674 * * * \\
(50,502)\end{array}$ & & $\begin{array}{r}0.0640 * * * \\
(0.00812)\end{array}$ & \\
\hline InRoom & & $\begin{array}{c}4,523,583^{* * *} \\
(535,692)\end{array}$ & & $\begin{array}{r}0.559 * * * \\
(0.0808)\end{array}$ \\
\hline Cement_wall & $\begin{array}{c}966,748 \\
(709,096)\end{array}$ & $\begin{array}{c}658,137 \\
(776,501)\end{array}$ & $\begin{array}{c}0.271^{* *} \\
(0.114)\end{array}$ & $\begin{array}{c}0.236^{* *} \\
(0.116)\end{array}$ \\
\hline Cement_floor & $\begin{array}{c}937,770 \\
(1,288,548)\end{array}$ & $\begin{array}{c}1,026,440 \\
(1,411,911)\end{array}$ & $\begin{array}{l}0.401^{*} \\
(0.205)\end{array}$ & $\begin{array}{l}0.391^{*} \\
(0.209)\end{array}$ \\
\hline Medium & $\begin{array}{c}-2,249,877^{* * *} \\
(853,428)\end{array}$ & $\begin{array}{c}-2,769,130 * * * \\
(930,924)\end{array}$ & $\begin{array}{l}-0.228^{*} \\
(0.135)\end{array}$ & $\begin{array}{l}-0.268^{*} \\
(0.138)\end{array}$ \\
\hline Degraded & $\begin{array}{c}-2,279,469 * * \\
(1,047,989)\end{array}$ & $\begin{array}{c}-3,179,003^{* * *} \\
(1,140,821)\end{array}$ & $\begin{array}{l}-0.313^{*} \\
(0.170)\end{array}$ & $\begin{array}{c}-0.396^{* *} \\
(0.172)\end{array}$ \\
\hline Unfinished & $\begin{array}{c}-1,964,841^{* *} \\
(980,634)\end{array}$ & $\begin{array}{c}-2,743,944^{* *} \\
(1,069,291)\end{array}$ & $\begin{array}{l}-0.263^{*} \\
(0.156)\end{array}$ & $\begin{array}{c}-0.320^{* *} \\
(0.158)\end{array}$ \\
\hline Elec & $\begin{array}{c}149,345 \\
(517,490)\end{array}$ & $\begin{array}{c}201,326 \\
(573,578)\end{array}$ & $\begin{array}{l}0.170^{* *} \\
(0.0837)\end{array}$ & $\begin{array}{c}0.152^{*} \\
(0.0863)\end{array}$ \\
\hline Latrine_MDG & $\begin{array}{c}53,529 \\
(594,207)\end{array}$ & $\begin{array}{c}143,033 \\
(651,069)\end{array}$ & $\begin{array}{l}-0.0139 \\
(0.0934)\end{array}$ & $\begin{array}{r}-0.00646 \\
(0.0952)\end{array}$ \\
\hline Piped_water & $\begin{array}{c}2,899,072^{* * *} \\
(930,504)\end{array}$ & $\begin{array}{c}3,478,070^{* * *} \\
(1,016,623)\end{array}$ & $\begin{array}{c}0.115 \\
(0.147)\end{array}$ & $\begin{array}{c}0.175 \\
(0.150)\end{array}$ \\
\hline$\sigma_{\mathrm{u}}$ & $\begin{array}{l}718,608^{* *} \\
(348,416)\end{array}$ & $\begin{array}{c}784,342^{* *} \\
(368,520)\end{array}$ & $\begin{array}{c}0.209 * * * \\
(0.0773)\end{array}$ & $\begin{array}{r}0.223 * * * \\
(0.0763)\end{array}$ \\
\hline$\sigma_{\varepsilon}$ & $\begin{array}{c}3,730,027^{* * *} \\
(164,256)\end{array}$ & $\begin{array}{c}4,086,029 * * * \\
(179,494)\end{array}$ & $\begin{array}{c}0.581^{* * *} \\
(0.0267)\end{array}$ & $\begin{array}{r}0.593 * * * \\
(0.0271)\end{array}$ \\
\hline$\rho$ & 0.0357 & 0.0355 & 0.1140 & 0.1243 \\
\hline Constant & $\begin{array}{c}-178,236 \\
(1,698,285)\end{array}$ & $\begin{array}{l}-3,448,874 * \\
(2,057,535)\end{array}$ & $\begin{array}{c}14.07 * * * \\
(0.279)\end{array}$ & $\begin{array}{c}13.58 * * * \\
(0.314)\end{array}$ \\
\hline$R^{2}$ & 0.2705 & 0.2014 & 0.2305 & 0.2049 \\
\hline Log likelihood & -4588.61 & -4613.83 & -252.71 & -258.73 \\
\hline Observations & 277 & 277 & 277 & 277 \\
\hline $\begin{array}{l}\text { Number of } \\
\text { districts }\end{array}$ & 24 & 24 & 24 & 24 \\
\hline
\end{tabular}


Table 5. Hedonic price model for mud houses

\begin{tabular}{|c|c|c|c|c|}
\hline VARIABLES & $\begin{array}{l}\text { Model E } \\
\text { Lin_lin }\end{array}$ & $\begin{array}{l}\text { Model F } \\
\text { Lin_log }\end{array}$ & $\begin{array}{l}\text { Model G } \\
\text { Log_lin }\end{array}$ & $\begin{array}{c}\text { Model H } \\
\text { Log_log }\end{array}$ \\
\hline Room & $\begin{array}{c}142,233^{* *} \\
(68,038)\end{array}$ & & $\begin{array}{c}0.0427^{* *} \\
(0.0182)\end{array}$ & \\
\hline InRoom & & $\begin{array}{c}1,097,635^{* *} \\
(500,172)\end{array}$ & & $\begin{array}{c}0.301^{* *} \\
(0.141)\end{array}$ \\
\hline Cement_wall & $\begin{array}{l}1,043,602 \\
(1042472)\end{array}$ & $\begin{array}{c}1,065,110 \\
(1,033,810)\end{array}$ & $\begin{array}{c}0.241 \\
(0.328)\end{array}$ & $\begin{array}{c}0.246 \\
(0.329)\end{array}$ \\
\hline Cement_floor & $\begin{array}{c}1,482,676^{*} \\
(857,084)\end{array}$ & $\begin{array}{c}1,517,654^{*} \\
(849,123)\end{array}$ & $\begin{array}{c}1.074 * * * \\
(0.252)\end{array}$ & $\begin{array}{c}1.089 * * * \\
(0.253)\end{array}$ \\
\hline Medium & $\begin{array}{c}-74,819 \\
(2,242,777)\end{array}$ & $\begin{array}{c}-55,756 \\
(2,222,024)\end{array}$ & $\begin{array}{l}0.0300 \\
(0.694)\end{array}$ & $\begin{array}{l}0.0341 \\
(0.697)\end{array}$ \\
\hline Degraded & $\begin{array}{c}-59,220 \\
(2,173,287)\end{array}$ & $\begin{array}{c}-61,457 \\
(2,154,066)\end{array}$ & $\begin{array}{l}0.0462 \\
(0.681)\end{array}$ & $\begin{array}{l}0.0441 \\
(0.683)\end{array}$ \\
\hline Unfinished & $\begin{array}{c}454,526 \\
(2,256,026)\end{array}$ & $\begin{array}{c}527,298 \\
(2,237,266)\end{array}$ & $\begin{array}{c}0.428 \\
(0.715)\end{array}$ & $\begin{array}{c}0.430 \\
(0.717)\end{array}$ \\
\hline Elec & $\begin{array}{c}250,318 \\
(727,281)\end{array}$ & $\begin{array}{c}396,579 \\
(712,851)\end{array}$ & $\begin{array}{c}0.189 \\
(0.205)\end{array}$ & $\begin{array}{c}0.241 \\
(0.201)\end{array}$ \\
\hline Latrine_MDG & $\begin{array}{c}154,878 \\
(1,192,094)\end{array}$ & $\begin{array}{c}174,984 \\
(1,180,518)\end{array}$ & $\begin{array}{c}0.483 \\
(0.378)\end{array}$ & $\begin{array}{c}0.491 \\
(0.379)\end{array}$ \\
\hline Piped_water & $\begin{array}{c}-163,987 \\
(2,147,622)\end{array}$ & $\begin{array}{c}-569,849 \\
(2,129,041)\end{array}$ & $\begin{array}{l}-0.142 \\
(0.684)\end{array}$ & $\begin{array}{l}-0.249 \\
(0.684)\end{array}$ \\
\hline$\sigma_{\mathrm{u}}$ & $\begin{array}{c}6,401,746 * * * \\
(1,001,270)\end{array}$ & $\begin{array}{c}6,545,430 * * * \\
(1,003,718)\end{array}$ & $\begin{array}{c}0.376^{* * *} \\
(0.106)\end{array}$ & $\begin{array}{c}0.382^{* * *} \\
(0.110)\end{array}$ \\
\hline$\sigma_{\varepsilon}$ & $\begin{array}{c}1,938,505^{* * *} \\
(155,887)\end{array}$ & $\begin{array}{c}1,921,120 * * * \\
(153,537)\end{array}$ & $\begin{array}{c}0.631 * * * \\
(0.0506)\end{array}$ & $\begin{array}{r}0.633^{* * *} \\
(0.0512)\end{array}$ \\
\hline$\rho$ & 0.916008 & 0.920686 & 0.261828 & 0.266560 \\
\hline Constant & $\begin{array}{c}1,837,851 \\
(2,644,175)\end{array}$ & $\begin{array}{c}798,262 \\
(2,745,553)\end{array}$ & $\begin{array}{c}13.19 * * * \\
(0.725)\end{array}$ & $\begin{array}{c}12.93 * * * \\
(0.755)\end{array}$ \\
\hline $\mathrm{R}^{2}$ & 0.0666 & 0.0524 & 0.1594 & 0.1535 \\
\hline Log likelihood & -1764.79 & -1764.61 & -114.79 & -115.24 \\
\hline Observations & 108 & 108 & 108 & 108 \\
\hline $\begin{array}{l}\text { Number of } \\
\text { districts }\end{array}$ & 26 & 26 & 26 & 26 \\
\hline
\end{tabular}


Table 6. Implicit marginal prices for Model C

\begin{tabular}{lc}
\hline VARIABLES & $\begin{array}{c}\text { Implicit } \\
\text { marginal price }\end{array}$ \\
\hline Room & 295,203 \\
Cement_wall & $1,250,001$ \\
Cement_floor & $1,849,633$ \\
Medium & $-1,051,661$ \\
Degraded & $-1,443,728$ \\
Unfinished & $-1,213,101$ \\
Elec & 784,133 \\
Piped_water & $-64,114$ \\
Latrine_MDG & 530,443 \\
\hline
\end{tabular}


Table 7. Implicit marginal prices for celibatoriums for all types of latrines

\begin{tabular}{|c|c|c|}
\hline VARIABLES & $\begin{array}{c}\text { Log_lin } \\
\text { InHousing_value }\end{array}$ & $\begin{array}{c}\text { Implicit Marginal } \\
\text { Price }\end{array}$ \\
\hline Room & $\begin{array}{c}0.0633 * * * \\
(0.00806)\end{array}$ & 291974.53 \\
\hline Cement_wall & $\begin{array}{c}0.282^{* *} \\
(0.112)\end{array}$ & 1300739.61 \\
\hline Cement_floor & $\begin{array}{l}0.376^{*} \\
(0.201)\end{array}$ & 1734319.48 \\
\hline Medium & $\begin{array}{l}-0.237^{*} \\
(0.132)\end{array}$ & -1093174.78 \\
\hline Degraded & $\begin{array}{l}-0.292^{*} \\
(0.166)\end{array}$ & -1346865.13 \\
\hline Unfinished & $\begin{array}{l}-0.255^{*} \\
(0.152)\end{array}$ & -1176200.71 \\
\hline Elec & $\begin{array}{c}0.115 \\
(0.0850)\end{array}$ & 530443.458 \\
\hline Piped_water & $\begin{array}{c}0.130 \\
(0.145)\end{array}$ & 599631.736 \\
\hline Latrine_VIP & $\begin{array}{l}0.228^{*} \\
(0.134)\end{array}$ & 1051661.81 \\
\hline Latrine_Ecosan & $\begin{array}{l}-0.357 \\
(0.306)\end{array}$ & -1646681 \\
\hline Latrine_TMC & $\begin{array}{l}0.0905 \\
(0.165)\end{array}$ & 417435.939 \\
\hline Latrine_Modern & $\begin{array}{l}-0.384 \\
(0.352)\end{array}$ & -1771219.9 \\
\hline Latrine_Public & $\begin{array}{c}0.00846 \\
(0.237)\end{array}$ & 39022.1883 \\
\hline Latrine_Traditional & $\begin{array}{l}0.184^{* *} \\
(0.0917)\end{array}$ & 848709.534 \\
\hline$\sigma_{\mathrm{u}}$ & $\begin{array}{l}0.218 * * * \\
(0.0750)\end{array}$ & \\
\hline$\sigma_{\varepsilon}$ & $\begin{array}{l}0.569 * * * \\
(0.0260)\end{array}$ & \\
\hline$\rho$ & 0.1277 & \\
\hline Constant & $\begin{array}{c}14.01 * * * \\
(0.274)\end{array}$ & \\
\hline$R^{2}$ & 0.3436 & \\
\hline Log likelihood & -248.36 & \\
\hline Observations & 278 & \\
\hline Number of Districts & 24 & \\
\hline
\end{tabular}

Moreover, it is necessary to take into account the endogeneity that may exist between the price of the dwellings and the quantities of characteristics. Indeed the buyer can simultaneously choose the price and some characteristics. In the presence of endogeneity, the coefficients of the 
different characteristics estimated would be biased and inconsistent, the explanatory variable(s) being correlated with residuals of the regression (Cavailhès, 2005). As we suspect the number of rooms to be endogenous, we define two instruments: the number of households in the dwelling and the number of individuals. These are correlated with the number of rooms but not with the housing value. The test of overidentified restrictions suggests that we cannot reject the null hypothesis that the instruments are uncorrelated with the error term in the structural model. However, conducting the Hausman test for endogeneity leads to a p-value of 0.9993 . Hence, we cannot reject the null hypothesis that the number of rooms is exogenous.

\section{Results and discussion}

The estimation of the hedonic price function, previously performed, shows the importance of the intrinsic characteristics of the celibatoriums in the study area. Indeed, the implicit price of rooms is high. Having a medium, degraded or unfinished home decreases its value compared to an excellent home (cf. Table 4, 6 and 7). Having electricity and water leads to an increase of the housing value (Table 4, Model C). Our estimates therefore highlight the importance of access to basic services, such as water and electricity. Regarding latrines, our results (Table 7) highlight the capitalization of VIP and Traditional latrines compared to using the nature for households living in celibatoriums. Such results are in line with expected results.

Despite considerable efforts, water, sanitation, and hygiene remain striking issues in developing countries. Actions emanating from the civil society, governments, NGOs, donors, and foundations are countless (education programs, investments, etc.). However, the issue still needs to be tackled. The particular issue of latrines affects several key dimensions of the human being: the spread of infectious disease, the quality of the immediate environment, his/her dignity, and, therefore more widely, quality of life (Jenkins and Curtis, 2005).

Our results support the idea that the presence of certain types of latrines is positively capitalized in housing values. This can cause two effects. On the one hand, to purchase/sell in the real estate market, house prices with latrines will be higher due to a premium linked to their presence. Thus, only one category of households, probably richer, will have the ability to pay for these homes. On the other hand, on the rental market, we may expect this premium to increase rental values and thus affect poorer households. This argument is supported by existing studies that find a positive relationship between rents and the presence of toilets, e.g. Knight et al. (2004) in Uganda and Gulyani and Talukdar (2008) in Kenya.

As raised by Malpezzi et al. (1985), information on the functioning of housing markets in developing countries remains relatively scarce compared to that of developed countries, although necessary for policy makers when addressing urban policies. What is more, "in developing countries, only a small number of studies have been done, and these are only linked to policy applications" (Malpezzi et al., 1985 p. 15). Water and sanitation policies are part of the wider problem of land management in African cities. In the context of the Millennium Development Goals (MDGs), governments supported by donors and NGOs invest in many programs related to the production and distribution of drinking water and sanitation to improve households' well-being. The crucial question raised by these development actors is whether projects that are intended to help the most disadvantaged populations really benefit them. And more generally, to what extent does their operation contribute to the fight against poverty? 
Our analysis aims at investigating the unexpected or unintended effects of programsinitially aimed at improving access to water and other basic services-on the targeted populations. In our econometric model, we question whether there is a positive relationship between property prices, piped water, and sanitation, and the underlying idea that the improvement of water and sanitation infrastructure has an effect on the standing of a neighborhood. To our knowledge, this is the first analysis of the value of housing attributes in Togo.

One major consequence of a positive relationship between house values, water, and sanitation could be the eviction of the poorest people in these neighborhoods. Rakodi (1992) refers to the "...'hijacking' of housing or plots intended for the poor by higher income groups" and emphasizes the "realization that housing for the urban poor must be considered within the context of the housing sector as a whole." These people will most often move a little further out, most commonly to areas lacking basic services (water, sanitation, electricity, education, health, and so forth). This is partly responsible for the constant expansion of cities to the periphery and the development of many neighborhoods, for which the literature provides different names depending on the location and context (informal devices, suburbs, slums, and the like). The development of these areas generates many problems.

The first is land policy for regulating urban sprawl. The second is the lack of, or even total absence of, the provision of basic services (such as water, sanitation, electricity, education, and health). We argue that policies should not act only to improve the provision of these services, but that such policies should be accompanied by housing and tenure measures in order to avoid these unintended effects. In Togo, like in many developing world cities, water policy relies on projecttargeting or a project-oriented approach. We argue that urban services and housing ought to be considered in a holistic way. This idea is also shared by Rakodi (1992), Mayo et al. (1986), and Archambault et al. (2012).

Further analysis is needed, though; indeed, even if other studies (like Megbolugbe, 1989, in Nigeria; Knight et al., 2004, in Uganda; and Gulyani and Talukdar, 2008 in Kenya) find positive correlation between water and sanitation services and housing values/rents, there is not yet enough evidence. Housing and urbanization is and will continue to be a major factor in African cities (Collier and Venables, 2013). Therefore, more research should be devoted to this matter.

Finally, performing a cost-benefit analysis for urban service in African cities should be considered. Even if studies find that tap water and sanitation increases home values or rental, tap water often is less costly than private vendors, as noted, for instance, by Gulyani and Bassett (2007). One should also take into account the premium households shall pay when given access to tap water or private latrines, in order to fully capture the cost of access. Indeed, as argued by Malpezzi (1999), intervention in the housing market or infrastructure should be accompanied by an analysis of how the interventions change prices.

\section{Conclusion}

The purpose of this article was to examine, in the context of an African city, the impact of housing characteristics on housing values using the hedonic price method. The implementation of this method in the city of Dapaong, Togo reveals the importance of intrinsic characteristics.

Hence, these results indicate that the HPM may be a significant tool for the development of a city in the developing world. Indeed, in the context of studying the growth and financing of the "African city", water policy--whether through public or private provision and whether funded 
domestically or through international funding--meets a vital need of the population. Indeed, the provision of drinking water and sanitation cannot be reduced to a vector of development and differentiation of a neighborhood or a city through the promotion of a pleasant lifestyle. Beyond the immediate effects on health, access to water and sanitation has a considerable impact on households in developing countries. In fact, have a decent housing, for example, would increase women's access to the labor market (Malpezzi, 1999 ; Collier and Venables, 2013), as they would have less work at home, such as collecting water. The revealed importance of sanitation in the issue of urban development contributes to rendering public decision-making even more complex-not only do households have to pay for their water consumption, but they also have to pay a premium to have access to sanitation in their homes. In this context, the implementation of a second step would be to assess the actual cost to households of accessing these sanitation services, with a view to streamlining public decision and international funding, through such a cost-benefit analysis.

\section{References}

Ahmad, J., Goldar, B., Misra, S., 2005. Value of arsenic-free drinking water to rural households in Bangladesh. Journal of Environmental Management 74, 173-185.

Anselin, L., 2008. Valuing access to water-a spatial hedonic approach applied to Indian cities. World Bank Publications.

Archambault, C.S., de Laat, J., Zulu, E.M., 2012. Urban Services and Child Migration to the Slums of Nairobi. World Development 40, 1854-1869.

Arimah, B., 1992. Hedonic Prices and the Demand for Housing Attributes in a Third World City: The Case of Ibadan, Nigeria. Urban Studies 29, 639-651.

Asabere, P.K., 1981a. The Determinants of Land Values in an African City: The Case of Accra, Ghana. Land Economics 57, 385.

Asabere, P.K., 1981b. THE PRICE OF URBAN LAND IN A CHIEFDOM: EMPIRICAL EVIDENCE ON A TRADITIONAL AFRICAN CITY, KUMASI. Journal of Regional Science 21, 529-539.

Asabere, P.K., 2004. The Pricing of the Emergent Leasehold (Possessory) Estates of Ghana. Real Estate Economics 32, 673-694.

Bertrand, M., 2011. De Bamako à Accra mobilités urbaines et ancrages locaux en Afrique de l'Ouest. Karthala, Paris.

Briand, A., Loyal Laré, A., 2013. La demande de raccordement des ménages auprès des petits opérateurs privés d'eau potable: Le cas des quartiers périphériques de Maputo. Revue économique 64, 685-719.

Briand, A., Nauges, C., Strand, J., Travers, M., 2009a. The impact of tap connection on water use: the case of household water consumption in Dakar, Senegal. Environment and Development Economics 15, 107.

Briand, A., Nauges, C., Travers, M., 2009b. Les déterminants du choix d'approvisionnement en eau des ménages de Dakar. Revue d'économie du développement 23, 83.

Cavailhès, J., 2005. Le prix des attributs du logement. Économie et statistique 381, 91-123.

Choumert, J., Stage, J., Uwera, C., 2013. Access to water as a determinant of rental values: A hedonic analysis in Rwanda. Working paper.

Collier, P., Venables, A.J., 2013. Logement et urbanisation en Afrique: Libérer le développement du marché formel.

Cropper, M.L., Deck, L.B., McConnell, K.E., 1988. On the choice of funtional form for hedonic price functions. The Review of Economics and Statistics 668-675. 
Davidson, R., MacKinnon, J.G., 1981. Several Tests for Model Specification in the Presence of Alternative Hypotheses. Econometrica 49, 781-793.

De Oca, G.S.M., Bateman, I.J., Tinch, R., Moffatt, P.G., Bateman, I.J., 2003. Assessing the willingness to pay for maintained and improved water supplies in Mexico City. CSERGE Working Paper ECM 03-11.

Els, M., Von Fintel, D., 2010. Residential property prices in a submarket of South Africa: Separating real returns from attribute growth. South African Journal of Economics 78, 418-436.

Greene, W.H., 2003. Econometric Analysis. Pearson Education.

Gulyani, S., Bassett, E.M., 2007. Retrieving the baby from the bathwater: slum upgrading in SubSaharan Africa. Environment and Planning C: Government and Policy 25, 486-515.

Gulyani, S., Talukdar, D., 2008. Slum Real Estate: The Low-Quality High-Price Puzzle in Nairobi's Slum Rental Market and its Implications for Theory and Practice. World Development 36, 19161937.

Houdeingar, D.N., 2009. L'accès à la terre en Afrique subsaharienne, in: L'accès à La Terre et Ses Usages: Variations Internationales Access to Land and Its Use: Differing International Approaches.

Hutton, G., Haller, L., Bartram, J., 2007. Economic and health effects of increasing coverage of low cost household drinking water supply and sanitation interventions. World Health Organization.

Jenkins, M.W., Curtis, V., 2005. Achieving the "good life": Why some people want latrines in rural Benin. Social Science \& Medicine 61, 2446-2459.

Jones, K., 1991. Multi-level models for geographical research, Concepts and techniques in modern geography. Order from Environmental Publications, University of East Anglia, Norwich.

Jones, K., Bullen, N., 1994. Contextual models of urban house prices: a comparison of fixed-and random-coefficient models developed by expansion. Economic Geography 252-272.

Kayaga, S., Calvert, J., Sansom, K., 2003. Paying for water services: effects of household characteristics. Utilities Policy 11, 123-132.

Knight, J.R., Herrin, W.E., Balihuta, A.M., 2004. Housing prices and maturing real estate markets: Evidence from Uganda. The Journal of Real Estate Finance and Economics 28, 5-18.

MacKinnon, J.G., White, H., Davidson, R., 1983. Tests for model specification in the presence of alternative hypotheses: Some further results. Journal of Econometrics 21, 53-70.

Malpezzi, S., 1999. Chapter 44 Economic analysis of housing markets in developing and transition economies, in: Handbook of Regional and Urban Economics. Elsevier, pp. 1791-1864.

Malpezzi, S., Mayo, S.K., Gross, 1985. Housing demand in developing countries. World Bank, Washington, D.C., U.S.A.

Mayo, S.K., Malpezzi, S., Gross, D.J., 1986. Shelter strategies for the urban poor in developing countries. The World Bank Research Observer 1, 183-203.

Megbolugbe, I., 1989. A Hedonic Index Model: The Housing Market of Jos, Nigeria. Urban Studies 26, 486-494.

Nauges, C., Strand, J., 2007. Estimation of non-tap water demand in Central American cities. Resource and Energy Economics 29, 165-182.

Nauges, C., Strand, J., Walker, I., 2008. The value of water connections in Central American cities: a revealed preference study. Environment and Development Economics 14, 349.

Nauges, C., Van Den Berg, C., 2009. Perception of health risk and averting behavior: An analysis of household water consumption in Southwest Sri Lanka. TSE Working Paper 9.

Nauges, C., Whittington, D., 2009. Estimation of Water Demand in Developing Countries: An Overview. The World Bank Research Observer 25, 263-294.

North, J.H., Griffin, C.C., 1993. Water source as a housing characteristic: Hedonic property valuation and willingness to pay for water. Water Resources Research 29, 1923-1929. 
Onjala, J., Wagura Ndiritu, S., Stage, J., 2013. Risk Perception, Choice of Drinking Water, and Water Treatment Evidence from Kenyan Towns. EfD Discussion Paper EfD.

Orford, S., 2000. Modelling spatial structures in local housing market dynamics: a multilevel perspective. Urban Studies 37, 1643-1671.

Rakodi, C., 1992. Housing markets in third world cities: Research and policy into the 1990s. World Development 20, 39-55.

Rosen, S., 1974. Hedonic Prices and Implicit Markets: Product Differentiation in Pure Competition. Journal of Political Economy 82, 34-55.

Stage, J., Uwera, C., 2012. Water management and pricing in the urban areas of Rwanda: the case of Kigali city. Water Utility Management International 7, 13-17.

UNDP, 2010. Les progrès vers l'atteinte des OMD au Togo.

UNFPA, 2007. L'état de la population mondiale 2007 : libérer le potentiel de la croissance urbaine. www.unfpa.org

Van den Berg, C., Nauges, C., 2012. The willingness to pay for access to piped water: a hedonic analysis of house prices in Southwest Sri Lanka. Letters in Spatial and Resource Sciences 5 , 151-166.

Whittington, D., Jeuland, M., Barker, K., Yuen, Y., 2012. Setting Priorities, Targeting Subsidies among Water, Sanitation, and Preventive Health Interventions in Developing Countries. World Development 40, 1546-1568.

Whittington, D., Lauria, D.T., Choe, K., Hughes, J.A., Swarna, V., Wright, A.M., 1993. Household sanitation in Kumasi, Ghana: a description of current practices, attitudes, and perceptions. World Development 21, 733-748.

Yusuf, A.A., Koundouri, P., 2004. Household's Valuation of Domestic Water in Indonesia: Revisiting the Supply Driven Approach. 


\section{Sampling}

The sample was constructed on the basis of data provided by the Regional Office of Statistics (Direction Régionale de la Statistique, 2010 estimation). The following definitions were used:

- Household: A group of individuals having or not having a relationship, living in the same dwelling, taking meals together and having the same family budget (INE, 2006). In some cases, we can find a group of individuals who live in the same house without sharing the same budget. In this case, we consider each person as an independent household. Military barracks, residential schools, colleges, hospitals, and prisons are considered as "collective" households, so voluntarily excluded from our study.

- The head of household: Person (male or female) recognized as such by other household members. This person assumes responsibility for the family. Each household necessarily has a leader. This individual may or may not be present at the time of the survey (INE, 2006).

- Household member: Individual living (eating and sleeping) in the household. He/she may be present or absent at the time of the interview. Note: Included in this category are employees who live (eat and sleep) in the household and long-term visitors located in the household (INE, 2006).

\section{Sampling: two-stage sampling}

The survey was conducted in the form of a stratified, simple, random sampling. The first level consisted of, first, cutting the city into small geographic areas. Four areas have been established. The second degree is a second, random drawing but this time in the households in the four areas above, ensuring there are interviews in each district.

Regarding the selection of households: there was systematic selection with only the first household randomly selected. The following households were selected by counting "steps" (the value of "steps" differs depending on the neighborhood, since all districts do not have the same sample size) from the first randomly selected household. After arriving in a district, each investigator started from the center, each taking a different direction (north, south, east, or west) respecting the step value-this, to better disperse the sample and to comply with the random selection of households. If someone refused to answer the questionnaire, the investigator would go to the first neighbor.

\section{Sample Size}

The sampling unit is the household. Specific factors have been taken into account in determining the size of the sample: (i) ensure the statistical power of the sample to conduct statistical and econometric analyses and (ii) have a handy sample to ensure a proper system of quality control at all stages. Calculating the sample size was made in three steps:

(1) Calculation of the sample size base. Three factors are decisive for the calculation of the sample size in this study: The estimated prevalence of the studied variables (i.e. rate of access to water or 
sanitation), namely, the rate of access to improved sanitation: $\mathrm{p}$; the confidence level under $\mathrm{T}$; and the acceptable margin of error: $\mathrm{m}$. In this case, the rate of access to improved sanitation was $13 \%$ in 2010 (JMP, 2012), which gives us the following parameters: $P=13 \%, m=5 \%$, and $T=1.96$ (for a confidence level of $95 \%)$. The central limit theorem states that if a random sample of size $n(n>30)$ is taken from a population in which the average frequency of the population is $f$, then the sampling distribution (or law of the estimator $p$ of $f$ ) approximately follows a normal distribution $\mathrm{N}$ of mean $\mathrm{p}$ and standard deviation $\sigma(\mathrm{f})$ with:

$$
\sigma(f)=\sqrt{p \frac{1-p}{n}}
$$

With the assumption of a sample with replacement, one must choose $n$ such that $T^{*} \sigma(p) \leq m$ with $T$ (random variable) $=1.96$, which gives

$$
n=\frac{T^{2} p(1-p)}{m^{2}}
$$

Therefore, the minimum size required for the sample is given by the latter. After calculation, the value of the sample found is 173 households or units of observations.

(2) Correction of clustering effects due to the choice of distribution units. The sample is based on a selection of 6 districts. To correct this, we multiply the sample size by this effect, often called the cluster effect (D). It is assumed, in general, that this cluster is equal to $2(D=2)$. With the correction, $n$ is equal to 347 households $(Z * 2)$.

(3) We must add to this figure a margin of $10 \%$ to account for non-responses or recording errors. This brings our value to 382 households, a figure that we will round to 400 households. 


\section{Distribution of households to investigate by region}

A sample of 400 households (according to calculations) was considered relevant. Given the high number of districts (26), we raised the number of households to 556 in order to have more households per district. This will be distributed in proportion to the size of each of the four study areas, as described in the following table:

Table A.1: Breakdown of the city into 4 zones and sample size

\begin{tabular}{|l|l|l|l|}
\hline \multicolumn{1}{|c|}{ Areas } & \multicolumn{1}{|c|}{ Districts concerned } & \multicolumn{1}{c|}{$\begin{array}{c}\text { Total } \\
\text { population }\end{array}$} & \multicolumn{1}{|c|}{$\begin{array}{c}\text { Sample } \\
\text { size }\end{array}$} \\
\hline Periphery (north and south) & $\begin{array}{l}\text { Sibortoti, Koni, Koutombong, Dalwak, } \\
\text { Dapankpergou, Badore, Batamboare, } \\
\text { Djangou }\end{array}$ & 9651 & 86 \\
\hline West-central & $\begin{array}{l}\text { Worgou, Tantigou, Nassable, } \\
\text { Kombonloaga, Natbagou }\end{array}$ & 18395 & 169 \\
\hline Est-central & $\begin{array}{l}\text { Boumong, Kounkoire, Nalolg, } \\
\text { Koutdjoak, Kampatib, Djamona }\end{array}$ & 13266 & 107 \\
\hline Centre & $\begin{array}{l}\text { Dadigou, Napieng, Kombondjonte, } \\
\text { Zongo, Bogliag, Kpegui, Bodjopal }\end{array}$ & 27338 & 194 \\
\hline Total & 26 districts & 68650 & 556 \\
\hline
\end{tabular}

${ }^{18}$ Data obtained from the Direction Régionale de la Statistique (estimation for 2010) 
Appendix B. Descriptive statistics for the full sample

\begin{tabular}{lcccc}
\hline & mean & sd & min & max \\
\hline Housing_value & 4612551.813 & 5053732.92 & 300000.0 & 40000000 \\
InHousing_value & 14.985 & 0.83 & 12.6 & 18 \\
\hline Room & 8.350 & 4.83 & 2 & 37 \\
InRoom & 1.981 & 0.53 & 0.7 & 4 \\
\hline Cement_wall & 0.622 & 0.49 & 0 & 1 \\
Adobe_wall & 0.311 & 0.46 & 0 & 1 \\
Adobe2_wall & 0.065 & 0.25 & 0 & 1 \\
\hline Cement_floor & 0.943 & 0.23 & 0 & 1 \\
Sand_floor & 0.018 & 0.13 & 0 & 1 \\
Clay_floor & 0.039 & 0.19 & 0 & 1 \\
\hline Medium & 0.443 & 0.50 & 0 & 1 \\
Degraded & 0.308 & 0.46 & 0 & 1 \\
Unfinished & 0.176 & 0.38 & 0 & 1 \\
Excellent & 0.065 & 0.25 & 0 & 1 \\
\hline Elec & 0.443 & 0.50 & 0 & 1 \\
\hline Piped_water & 0.057 & 0.23 & 0 & 1 \\
\hline Latrine_MDG & 0.153 & 0.36 & 0 & 1 \\
\hline Latrine_VIP & 0.083 & 0.28 & 0 & 1 \\
Latrine_Ecosan & 0.010 & 0.10 & 0 & 1 \\
Latrine_TMC & 0.052 & 0.22 & 0 & 1 \\
Latrine_Modern & 0.008 & 0.09 & 0 & 1 \\
Latrine_Public & 0.026 & 0.16 & 0 & \\
Latrine_Traditional & 0.440 & 0.50 & 0 & 0 \\
Latrine_Nature & 0.378 & 0.49 & & 0 \\
\hline$N$ & 386 & & & 0 \\
\hline
\end{tabular}




\begin{tabular}{|c|c|c|c|c|}
\hline & $\begin{array}{c}\text { Lin-lin } \\
\text { (Model A) }\end{array}$ & $\begin{array}{l}\text { Lin-log } \\
\text { (Model B) }\end{array}$ & $\begin{array}{l}\text { Log-lin } \\
\text { (Model C) }\end{array}$ & $\begin{array}{l}\text { Log-log } \\
\text { (Model D) }\end{array}$ \\
\hline \multirow{2}{*}{$\begin{array}{l}\text { Lin-lin } \\
\text { (Model A) }\end{array}$} & & $\begin{array}{l}J \text { test } \\
A \approx B\end{array}$ & $\begin{array}{l}P E \text { test } \\
C>A\end{array}$ & $\begin{array}{l}P E \text { test } \\
A \approx D\end{array}$ \\
\hline & & $\begin{array}{r}-1.261(0.000) \\
1.907(0.000)\end{array}$ & $\begin{array}{c}4054165(0.000) \\
-6.51 \mathrm{e}-09(0.817)\end{array}$ & $\begin{array}{l}5188348(0.000) \\
1.46 \mathrm{e}-07(0.006)\end{array}$ \\
\hline \multirow{2}{*}{$\begin{array}{l}\text { Lin-log } \\
\text { (Model B) }\end{array}$} & & & $\begin{array}{l}P E \text { test } \\
C>B\end{array}$ & $\begin{array}{c}P E \text { test } \\
B \approx D\end{array}$ \\
\hline & & & $\begin{array}{c}2604662(0.000) \\
-6.50 \mathrm{e}-09(0.725)\end{array}$ & $\begin{array}{c}2343344(0.000) \\
-2.57 \mathrm{e}-07(0.000)\end{array}$ \\
\hline \multirow{2}{*}{$\begin{array}{l}\text { Log-lin } \\
\text { (Model C) }\end{array}$} & & & & $\begin{array}{l}J \text { test } \\
C>D\end{array}$ \\
\hline & & & & $\begin{array}{l}-0.174(0.629) \\
1.143(0.000)\end{array}$ \\
\hline $\begin{array}{l}\text { Log-log } \\
\text { (Model D) }\end{array}$ & & & & \\
\hline
\end{tabular}

Appendix C. J-test for model comparison

\section{Comparison between models A, B, C and D for celibatoriums}

Comparison between models A, B, C and D for banco houses

\begin{tabular}{|c|c|c|c|c|}
\hline & $\begin{array}{c}\text { Lin-lin } \\
\text { (Model A) }\end{array}$ & $\begin{array}{c}\text { Lin-log } \\
\text { (Model B) }\end{array}$ & $\begin{array}{c}\text { Log-lin } \\
\text { (Model C) }\end{array}$ & $\begin{array}{l}\text { Log-log } \\
\text { (Model D) }\end{array}$ \\
\hline \multirow{2}{*}{$\begin{array}{l}\text { Lin-lin } \\
\text { (Model A) }\end{array}$} & & $\begin{array}{l}J \text { test } \\
A \approx B\end{array}$ & $\begin{array}{l}P E \text { test } \\
A \approx C\end{array}$ & $\begin{array}{l}P E \text { test } \\
A \approx D\end{array}$ \\
\hline & & $\begin{array}{l}0.824(0.529) \\
0.195(0.886)\end{array}$ & $\begin{array}{l}-1003436(0.925) \\
-1.19 e-08(0.973)\end{array}$ & $\begin{array}{l}3892730(0.489) \\
2.23 e-07(0.498)\end{array}$ \\
\hline \multirow{2}{*}{$\begin{array}{l}\text { Lin-log } \\
\text { (Model B) }\end{array}$} & & & $\begin{array}{c}P E \text { test } \\
B \approx C\end{array}$ & $\begin{array}{c}P E \text { test } \\
B \approx D\end{array}$ \\
\hline & & & $\begin{array}{l}764395.1(0.828) \\
-2.36 e-08(0.912)\end{array}$ & $\begin{array}{l}2583963(0.779) \\
-8.46 \mathrm{e}-08(0.831)\end{array}$ \\
\hline \multirow{2}{*}{$\begin{array}{l}\text { Log-lin } \\
\text { (Model C) }\end{array}$} & & & & $\begin{array}{l}J \text { test } \\
D \approx C\end{array}$ \\
\hline & & & & $\begin{array}{l}-0.213(0.874) \\
1.182(0.336)\end{array}$ \\
\hline $\begin{array}{l}\text { Log-log } \\
\text { (Model D) }\end{array}$ & & & & \\
\hline
\end{tabular}




\section{Tables available upon request to the authors}

Two-regime endogenous-switching model - Celibatorium

\begin{tabular}{|c|c|c|c|c|}
\hline VARIABLES & $\begin{array}{l}\text { Lin_lin } \\
\text { Housing_value }\end{array}$ & $\begin{array}{l}\text { Lin_log } \\
\text { Housing_value }\end{array}$ & $\begin{array}{l}\text { Log_lin } \\
\text { InHousing_value }\end{array}$ & $\begin{array}{c}\text { Log_log } \\
\text { InHousing_value }\end{array}$ \\
\hline IMR1 & $\begin{array}{c}4.983 e+06 \\
(5.468 e+06)\end{array}$ & $\begin{array}{c}4.449 \mathrm{e}+06 \\
(5.206 \mathrm{e}+06)\end{array}$ & $\begin{array}{c}0.805 \\
(0.947)\end{array}$ & $\begin{array}{c}0.666 \\
(0.751)\end{array}$ \\
\hline Room & $\begin{array}{c}619,410 * * * \\
(106,347)\end{array}$ & & $\begin{array}{c}0.0641 * * * \\
(0.00638)\end{array}$ & \\
\hline InRoom & & $\begin{array}{c}4.691 \mathrm{e}+06^{* * *} \\
(857,083)\end{array}$ & & $\begin{array}{c}0.565^{* * *} \\
(0.0839)\end{array}$ \\
\hline Cement_wall & $\begin{array}{c}1.826 \mathrm{e}+06 \\
(1.971 \mathrm{e}+06)\end{array}$ & $\begin{array}{c}1.387 \mathrm{e}+06 \\
(1.782 \mathrm{e}+06)\end{array}$ & $\begin{array}{c}0.352 \\
(0.283)\end{array}$ & $\begin{array}{c}0.286 \\
(0.227)\end{array}$ \\
\hline Cement_floor & $\begin{array}{c}816,298 \\
(992,628)\end{array}$ & $\begin{array}{c}846,951 \\
(1.360 e+06)\end{array}$ & $\begin{array}{c}0.431^{* *} \\
(0.191)\end{array}$ & $\begin{array}{l}0.408^{*} \\
(0.221)\end{array}$ \\
\hline Medium & $\begin{array}{c}-2.126 e+06^{*} \\
(1.227 e+06)\end{array}$ & $\begin{array}{c}-2.668 \mathrm{e}+06 \\
(1.828 \mathrm{e}+06)\end{array}$ & $\begin{array}{l}-0.236 \\
(0.151)\end{array}$ & $\begin{array}{l}-0.270^{*} \\
(0.164)\end{array}$ \\
\hline Degraded & $\begin{array}{c}-2.845 \mathrm{e}+06^{* *} \\
(1.318 \mathrm{e}+06)\end{array}$ & $\begin{array}{c}-3.754 \mathrm{e}+06 * * \\
(1.896 \mathrm{e}+06)\end{array}$ & $\begin{array}{c}-0.469 * * \\
(0.184)\end{array}$ & $\begin{array}{c}-0.536 * * * \\
(0.186)\end{array}$ \\
\hline Unfinished & $\begin{array}{c}-2.020 \mathrm{e}+06 \\
(1.271 \mathrm{e}+06)\end{array}$ & $\begin{array}{c}-2.870 \mathrm{e}+06 \\
(1.772 \mathrm{e}+06)\end{array}$ & $\begin{array}{l}-0.320^{*} \\
(0.177)\end{array}$ & $\begin{array}{c}-0.374 * * \\
(0.170)\end{array}$ \\
\hline Elec & $\begin{array}{c}167,983 \\
(551,197)\end{array}$ & $\begin{array}{c}157,520 \\
(521,565)\end{array}$ & $\begin{array}{c}0.118 \\
(0.0871)\end{array}$ & $\begin{array}{c}0.0976 \\
(0.0795)\end{array}$ \\
\hline Piped_water & $\begin{array}{l}2.813 \mathrm{e}+06^{*} \\
(1.696 \mathrm{e}+06)\end{array}$ & $\begin{array}{c}3.536 \mathrm{e}+06 \\
(2.322 \mathrm{e}+06)\end{array}$ & $\begin{array}{c}0.102 \\
(0.167)\end{array}$ & $\begin{array}{c}0.168 \\
(0.187)\end{array}$ \\
\hline Latrine_MDG & $\begin{array}{l}-147,620 \\
(730,730)\end{array}$ & $\begin{array}{c}-85,881 \\
(755,235)\end{array}$ & $\begin{array}{l}-0.0390 \\
(0.0915)\end{array}$ & $\begin{array}{l}-0.0322 \\
(0.0969)\end{array}$ \\
\hline Quart_Sibortoti & $\begin{array}{c}8.504 \mathrm{e}+06 * * * \\
(1.298 \mathrm{e}+06)\end{array}$ & $\begin{array}{c}8.748 \mathrm{e}+06 * * * \\
(1.669 \mathrm{e}+06)\end{array}$ & $\begin{array}{c}2.190 * * * \\
(0.336)\end{array}$ & $\begin{array}{c}2.307^{* * *} \\
(0.312)\end{array}$ \\
\hline Quart_Koni & $\begin{array}{c}8.500 \mathrm{e}+06^{* * *} \\
(1.795 \mathrm{e}+06)\end{array}$ & $\begin{array}{c}8.150 \mathrm{e}+06^{* * *} \\
(2.432 \mathrm{e}+06)\end{array}$ & $\begin{array}{c}2.536^{* * *} \\
(0.330)\end{array}$ & $\begin{array}{c}2.556 * * * \\
(0.414)\end{array}$ \\
\hline Quart_Nassable & $\begin{array}{c}9.021 \mathrm{e}+06 * * * \\
(1.311 \mathrm{e}+06)\end{array}$ & $\begin{array}{c}8.959 \mathrm{e}+06 * * * \\
(1.715 \mathrm{e}+06)\end{array}$ & $\begin{array}{c}2.555^{* * *} \\
(0.193)\end{array}$ & $\begin{array}{c}2.624 * * * \\
(0.179)\end{array}$ \\
\hline Quart_Natbagou & $\begin{array}{c}7.072 \mathrm{e}+06 * * * \\
(1.155 \mathrm{e}+06)\end{array}$ & $\begin{array}{c}6.406 \mathrm{e}+06 * * * \\
(1.498 \mathrm{e}+06)\end{array}$ & $\begin{array}{c}2.156^{* * *} \\
(0.205)\end{array}$ & $\begin{array}{c}2.147^{* * *} \\
(0.196)\end{array}$ \\
\hline Quart_Koutombong & $\begin{array}{c}6.755 e+06 * * * \\
(1.668 \mathrm{e}+06)\end{array}$ & $\begin{array}{c}6.322 \mathrm{e}+06^{* * *} \\
(1.516 \mathrm{e}+06)\end{array}$ & $\begin{array}{c}2.344 * * * \\
(0.278)\end{array}$ & $\begin{array}{c}2.318^{* * *} \\
(0.288)\end{array}$ \\
\hline Quart_Kombonloaga & $\begin{array}{c}7.490 \mathrm{e}+06 * * * \\
(1.499 \mathrm{e}+06)\end{array}$ & $\begin{array}{c}7.324 \mathrm{e}+06 * * * \\
(1.806 \mathrm{e}+06)\end{array}$ & $\begin{array}{c}2.207 * * * \\
(0.207)\end{array}$ & $\begin{array}{c}2.229 * * * \\
(0.218)\end{array}$ \\
\hline Quart_Kpegui & $\begin{array}{c}7.514 \mathrm{e}+06 * * * \\
(1.084 \mathrm{e}+06)\end{array}$ & $\begin{array}{c}7.074 \mathrm{e}+06 * * * \\
(1.265 \mathrm{e}+06)\end{array}$ & $\begin{array}{c}2.462 * * * \\
(0.207)\end{array}$ & $\begin{array}{c}2.462 * * * \\
(0.192)\end{array}$ \\
\hline Quart_Bodjopal & $8.577 e+06 * * *$ & $8.180 \mathrm{e}+06 * * *$ & $2.573 * * *$ & $2.589 * * *$ \\
\hline
\end{tabular}




\begin{tabular}{|c|c|c|c|c|}
\hline \multirow{2}{*}{ Quart_Bogliag } & $(1.179 \mathrm{e}+06)$ & $(1.380 \mathrm{e}+06)$ & $(0.221)$ & $(0.197)$ \\
\hline & $\begin{array}{c}6.517 e+06 * * * \\
(909,736)\end{array}$ & $\begin{array}{c}6.315 \mathrm{e}+06 * * * \\
(1.309 \mathrm{e}+06)\end{array}$ & $\begin{array}{c}2.263^{* * *} \\
(0.183)\end{array}$ & $\begin{array}{c}2.278 * * * \\
(0.167)\end{array}$ \\
\hline Quart_Zongo & $\begin{array}{c}7.797 \mathrm{e}+06^{* * *} \\
(1.479 \mathrm{e}+06)\end{array}$ & $\begin{array}{c}8.059 \mathrm{e}+06 * * * \\
(2.184 \mathrm{e}+06)\end{array}$ & $\begin{array}{c}2.445^{* * *} \\
(0.212)\end{array}$ & $\begin{array}{c}2.496 * * * \\
(0.173)\end{array}$ \\
\hline Quart_Tantigou & $\begin{array}{c}9.186 \mathrm{e}+06^{* * *} \\
(1.686 \mathrm{e}+06)\end{array}$ & $\begin{array}{c}9.401 \mathrm{e}+06 * * * \\
(2.199 \mathrm{e}+06)\end{array}$ & $\begin{array}{c}2.497 * * * \\
(0.247)\end{array}$ & $\begin{array}{c}2.557^{* * *} \\
(0.267)\end{array}$ \\
\hline Quart_Napieng & $\begin{array}{c}5.882 \mathrm{e}+06 * * * \\
(1.276 \mathrm{e}+06)\end{array}$ & $\begin{array}{c}6.465 e+06 * * * \\
(1.611 e+06)\end{array}$ & $\begin{array}{c}2.413 * * * \\
(0.240)\end{array}$ & $\begin{array}{c}2.481 * * * \\
(0.185)\end{array}$ \\
\hline Quart_Koutdjoak & $\begin{array}{c}8.902 \mathrm{e}+06^{* * *} \\
(1.326 \mathrm{e}+06)\end{array}$ & $\begin{array}{c}8.679 \mathrm{e}+06^{* * *} \\
(1.399 \mathrm{e}+06)\end{array}$ & $\begin{array}{c}2.573 * * * \\
(0.239)\end{array}$ & $\begin{array}{c}2.596 * * * \\
(0.256)\end{array}$ \\
\hline Quart_Kampatib & $\begin{array}{c}7.048 \mathrm{e}+06 * * \\
(3.026 \mathrm{e}+06)\end{array}$ & $\begin{array}{c}6.290 \mathrm{e}+06^{* *} \\
(2.939 \mathrm{e}+06)\end{array}$ & $\begin{array}{c}2.421 * * * \\
(0.342)\end{array}$ & $\begin{array}{c}2.412 * * * \\
(0.418)\end{array}$ \\
\hline Quart_Nalolg & $\begin{array}{c}9.878 \mathrm{e}+06 * * * \\
(1.474 \mathrm{e}+06)\end{array}$ & $\begin{array}{c}9.951 \mathrm{e}+06 * * * \\
(1.619 \mathrm{e}+06)\end{array}$ & $\begin{array}{c}2.601 * * * \\
(0.236)\end{array}$ & $\begin{array}{c}2.643^{* * *} \\
(0.215)\end{array}$ \\
\hline Quart_Djamona & $\begin{array}{c}1.075 \mathrm{e}+07^{* * *} \\
(1.944 \mathrm{e}+06)\end{array}$ & $\begin{array}{c}1.012 \mathrm{e}+07^{* * *} \\
(2.075 \mathrm{e}+06)\end{array}$ & $\begin{array}{c}2.887 * * * \\
(0.457)\end{array}$ & $\begin{array}{c}2.879 * * * \\
(0.369)\end{array}$ \\
\hline Quart_Dadigou & $\begin{array}{c}8.585 \mathrm{e}+06 * * * \\
(1.410 \mathrm{e}+06)\end{array}$ & $\begin{array}{c}7.544 \mathrm{e}+06 * * * \\
(1.702 \mathrm{e}+06)\end{array}$ & $\begin{array}{c}2.688^{* * * *} \\
(0.323)\end{array}$ & $\begin{array}{c}2.629 * * * \\
(0.347)\end{array}$ \\
\hline Quart_Konkoare & $\begin{array}{c}1.017 \mathrm{e}+07^{* * *} \\
(2.586 \mathrm{e}+06)\end{array}$ & $\begin{array}{c}1.008 \mathrm{e}+07^{* * *} \\
(3.186 \mathrm{e}+06)\end{array}$ & $\begin{array}{c}2.734^{* * *} \\
(0.273)\end{array}$ & $\begin{array}{c}2.771 * * * \\
(0.264)\end{array}$ \\
\hline Quart_Boumong & $\begin{array}{c}6.564 \mathrm{e}+06 * * * \\
(1.331 \mathrm{e}+06)\end{array}$ & $\begin{array}{c}5.942 \mathrm{e}+06 * * * \\
(1.379 \mathrm{e}+06)\end{array}$ & $\begin{array}{c}1.972 * * * \\
(0.194)\end{array}$ & $\begin{array}{c}1.979 * * * \\
(0.198)\end{array}$ \\
\hline Quart_Worgou & $\begin{array}{c}6.891 \mathrm{e}+06^{* * *} \\
(1.172 \mathrm{e}+06)\end{array}$ & $\begin{array}{c}6.402 \mathrm{e}+06 * * * \\
(1.720 \mathrm{e}+06)\end{array}$ & $\begin{array}{c}2.232 * * * \\
(0.226)\end{array}$ & $\begin{array}{c}2.261 * * * \\
(0.245)\end{array}$ \\
\hline \multirow[t]{2}{*}{$\begin{array}{l}\text { Quart_Dapankpergo } \\
\text { u }\end{array}$} & $5.369 \mathrm{e}+06 * * *$ & $4.997 \mathrm{e}+06^{* * *}$ & $1.598^{* * *}$ & $1.584^{* * *}$ \\
\hline & $(1.191 \mathrm{e}+06)$ & $(1.375 e+06)$ & $(0.317)$ & $(0.312)$ \\
\hline Quart_Badoré & $\begin{array}{c}5.027 \mathrm{e}+06 * * * \\
(1.700 \mathrm{e}+06)\end{array}$ & $\begin{array}{c}5.203 \mathrm{e}+06 * * * \\
(1.634 \mathrm{e}+06)\end{array}$ & $\begin{array}{r}-0.0455 \\
(0.174)\end{array}$ & $\begin{array}{l}0.0857 \\
(0.167)\end{array}$ \\
\hline $\begin{array}{l}\text { Quart_Kombondjont } \\
\text { e }\end{array}$ & $\begin{array}{c}7.356 \mathrm{e}+06 * * * \\
(1.396 \mathrm{e}+06)\end{array}$ & $\begin{array}{l}7.481 \mathrm{e}+06 * * * \\
(1.481 \mathrm{e}+06)\end{array}$ & $\begin{array}{l}2.633 * * * \\
(0.211)\end{array}$ & $\begin{array}{l}2.669 * * * \\
(0.208)\end{array}$ \\
\hline Constant & $\begin{array}{c}-1.033 \mathrm{e}+07 * * * \\
(3.700 \mathrm{e}+06)\end{array}$ & $\begin{array}{c}-1.317 e+07^{* *} \\
(5.277 e+06)\end{array}$ & $\begin{array}{c}11.43^{* * *} \\
(0.743)\end{array}$ & $\begin{array}{c}10.99 * * * \\
(0.575)\end{array}$ \\
\hline Observations & 276 & 276 & 276 & 276 \\
\hline R-squared & 0.533 & 0.436 & 0.515 & 0.491 \\
\hline
\end{tabular}

Standard errors in parentheses ${ }^{* * *} p<0.01,{ }^{* *} p<0.05,{ }^{*} p<0.1$

Two-regime endogenous-switching model - Banco

\begin{tabular}{lcccc} 
VARIABLES & $\begin{array}{c}\text { Lin_lin } \\
\text { Housing_value }\end{array}$ & $\begin{array}{c}\text { Lin_log } \\
\text { Housing_value }\end{array}$ & $\begin{array}{c}\text { Log_lin } \\
\text { InHousing_value }\end{array}$ & $\begin{array}{c}\text { Log_log } \\
\text { InHousing_value }\end{array}$ \\
\hline \multirow{2}{*}{ IMRO } & $9.033 \mathrm{e}+06$ & $9.536 \mathrm{e}+06$ & & \\
& $(6.024 \mathrm{e}+06)$ & $(6.641 \mathrm{e}+06)$ & $(2.609)$ & 2.777 \\
& &
\end{tabular}




\begin{tabular}{|c|c|c|c|c|}
\hline Room & $\begin{array}{c}126,334 \\
(103,475)\end{array}$ & & $\begin{array}{l}0.0352^{*} \\
(0.0190)\end{array}$ & \\
\hline InRoom & & $\begin{array}{c}1.038 \mathrm{e}+06^{* * *} \\
(401,730)\end{array}$ & & $\begin{array}{l}0.264^{*} \\
(0.156)\end{array}$ \\
\hline Cement_wall & $\begin{array}{l}-3.878 \mathrm{e}+06 \\
(3.156 e+06)\end{array}$ & $\begin{array}{c}-3.843 e+06^{*} \\
(2.281 e+06)\end{array}$ & $\begin{array}{l}-1.252 \\
(1.540)\end{array}$ & $\begin{array}{l}-1.335^{*} \\
(0.752)\end{array}$ \\
\hline Cement_floor & $\begin{array}{c}858,519 \\
(1.464 \mathrm{e}+06)\end{array}$ & $\begin{array}{c}614,602 \\
(644,119)\end{array}$ & $\begin{array}{c}0.880 * * * \\
(0.294)\end{array}$ & $\begin{array}{c}0.792 * * * \\
(0.292)\end{array}$ \\
\hline Medium & $\begin{array}{c}829,742 \\
(1.026 e+06)\end{array}$ & $\begin{array}{c}1.070 \mathrm{e}+06 \\
(738,198)\end{array}$ & $\begin{array}{l}0.238 \\
(0.241)\end{array}$ & $\begin{array}{c}0.324 \\
(0.370)\end{array}$ \\
\hline Degraded & $\begin{array}{c}609,298 \\
(773,199)\end{array}$ & $\begin{array}{c}862,994 * * \\
(372,411)\end{array}$ & $\begin{array}{l}0.152 \\
(0.244)\end{array}$ & $\begin{array}{c}0.239 \\
(0.292)\end{array}$ \\
\hline Unfinished & $\begin{array}{l}-1.005 e+06 \\
(1.584 e+06)\end{array}$ & $\begin{array}{l}-757,024 \\
(603,616)\end{array}$ & $\begin{array}{l}-0.292 \\
(0.415)\end{array}$ & $\begin{array}{l}-0.244 \\
(0.182)\end{array}$ \\
\hline Elec & $\begin{array}{l}-1.172 \mathrm{e}+06 \\
(1.229 \mathrm{e}+06)\end{array}$ & $\begin{array}{c}-921,178 \\
(1.225 \mathrm{e}+06)\end{array}$ & $\begin{array}{l}-0.399 \\
(0.257)\end{array}$ & $\begin{array}{c}-0.344^{* *} \\
(0.172)\end{array}$ \\
\hline Piped_water & $\begin{array}{l}-1.844 e+06 \\
(1.339 e+06)\end{array}$ & $\begin{array}{c}-2.308 \mathrm{e}+06^{* *} \\
(902,402)\end{array}$ & $\begin{array}{l}-0.441 \\
(0.688)\end{array}$ & $\begin{array}{l}-0.604 \\
(0.446)\end{array}$ \\
\hline Latrine_MDG & $\begin{array}{c}142,949 \\
(1.118 \mathrm{e}+06)\end{array}$ & $\begin{array}{c}57,947 \\
(500,736)\end{array}$ & $\begin{array}{c}0.500 * * * \\
(0.193)\end{array}$ & $\begin{array}{c}0.482^{* *} \\
(0.207)\end{array}$ \\
\hline Quart_Sibortoti & $\begin{array}{c}1.886 \mathrm{e}+06 \\
(1.853 \mathrm{e}+06)\end{array}$ & $\begin{array}{c}1.817 e+06 \\
(1.293 e+06)\end{array}$ & $\begin{array}{l}0.790^{*} \\
(0.479)\end{array}$ & $\begin{array}{c}0.761 \\
(0.575)\end{array}$ \\
\hline Quart_Koni & $\begin{array}{c}272,894 \\
(632,037)\end{array}$ & $\begin{array}{c}321,647 \\
(459,669)\end{array}$ & $\begin{array}{l}0.152 * * \\
(0.0718)\end{array}$ & $\begin{array}{c}0.170 \\
(0.376)\end{array}$ \\
\hline Quart_Nassable & $\begin{array}{c}499,534 \\
(638,249)\end{array}$ & $\begin{array}{c}784,689 \\
(733,242)\end{array}$ & $\begin{array}{c}0.456 \\
(0.316)\end{array}$ & $\begin{array}{c}0.512 \\
(0.345)\end{array}$ \\
\hline Quart_Natbagou & $\begin{array}{l}-163,239 \\
(682,325)\end{array}$ & $\begin{array}{l}-126,419 \\
(749,772)\end{array}$ & $\begin{array}{l}0.0899 \\
(0.440)\end{array}$ & $\begin{array}{l}0.0682 \\
(0.591)\end{array}$ \\
\hline Quart_Koutombong & $\begin{array}{l}-2.876 e+06 \\
(2.439 e+06)\end{array}$ & $\begin{array}{l}-2.966 e+06 \\
(1.924 e+06)\end{array}$ & $\begin{array}{l}-0.719 \\
(1.034)\end{array}$ & $\begin{array}{l}-0.819 \\
(0.693)\end{array}$ \\
\hline Quart_Kombonloaga & $\begin{array}{c}37,009 \\
(2.006 \mathrm{e}+06)\end{array}$ & $\begin{array}{c}-12,851 \\
(862,522)\end{array}$ & $\begin{array}{c}0.279 \\
(0.600)\end{array}$ & $\begin{array}{c}0.208 \\
(0.360)\end{array}$ \\
\hline Quart_Kpegui & $\begin{array}{c}7.259 \mathrm{e}+06 * * * \\
(1.338 \mathrm{e}+06)\end{array}$ & $\begin{array}{c}7.257 \mathrm{e}+06^{* * *} \\
(892,511)\end{array}$ & $\begin{array}{c}2.324 * * * \\
(0.218)\end{array}$ & $\begin{array}{c}2.332^{* * *} \\
(0.279)\end{array}$ \\
\hline Quart_Bodjopal & $\begin{array}{c}581,127 \\
(1.393 e+06)\end{array}$ & $\begin{array}{c}751,554 \\
(1.141 \mathrm{e}+06)\end{array}$ & $\begin{array}{c}0.703 \\
(0.520)\end{array}$ & $\begin{array}{l}0.698^{*} \\
(0.410)\end{array}$ \\
\hline Quart_Bogliag & $\begin{array}{c}2.393 \mathrm{e}+06 \\
(1.764 \mathrm{e}+06)\end{array}$ & $\begin{array}{c}2.189 \mathrm{e}+06^{* *} \\
(986,464)\end{array}$ & $\begin{array}{c}1.079 \\
(0.705)\end{array}$ & $\begin{array}{c}1.010^{* * *} \\
(0.365)\end{array}$ \\
\hline Quart_Zongo & $\begin{array}{c}1.362 \mathrm{e}+06^{* * *} \\
(518,904)\end{array}$ & $\begin{array}{c}1.338 \mathrm{e}+06^{* *} \\
(572,801)\end{array}$ & $\begin{array}{c}1.018^{* * *} \\
(0.103)\end{array}$ & $\begin{array}{c}1.009 * * * \\
(0.186)\end{array}$ \\
\hline Quart_Tantigou & $\begin{array}{c}3.477 \mathrm{e}+07^{* * *} \\
(1.859 \mathrm{e}+06)\end{array}$ & $\begin{array}{c}3.552 \mathrm{e}+07^{* * *} \\
(1.472 \mathrm{e}+06)\end{array}$ & $\begin{array}{c}2.668 * * * \\
(0.758)\end{array}$ & $\begin{array}{c}2.854^{* * *} \\
(0.686)\end{array}$ \\
\hline Quart_Napieng & $\begin{array}{c}4.084 \mathrm{e}+06 * * * \\
(1.584 \mathrm{e}+06)\end{array}$ & $\begin{array}{c}3.928 \mathrm{e}+06 * * \\
(1.532 \mathrm{e}+06)\end{array}$ & $\begin{array}{c}1.616^{* * *} \\
(0.417)\end{array}$ & $\begin{array}{c}1.580 * * * \\
(0.363)\end{array}$ \\
\hline Quart_Koutdjoak & $\begin{array}{c}4.530 \mathrm{e}+06 * * * \\
(1.240 \mathrm{e}+06)\end{array}$ & $\begin{array}{c}4.658 \mathrm{e}+06^{* * *} \\
(1.524 \mathrm{e}+06)\end{array}$ & $\begin{array}{c}1.558^{* * *} \\
(0.396)\end{array}$ & $\begin{array}{c}1.579 * * * \\
(0.422)\end{array}$ \\
\hline Quart_Kampatib & $\begin{array}{c}6.592 \mathrm{e}+06^{* * *} \\
(596,006)\end{array}$ & $\begin{array}{c}6.826 \mathrm{e}+06^{* * *} \\
(567,078)\end{array}$ & $\begin{array}{c}2.002^{* * *} \\
(0.255)\end{array}$ & $\begin{array}{c}2.079 * * * \\
(0.319)\end{array}$ \\
\hline Quart_Nalolg & $-1.357 e+06$ & $-1.561 e+06$ & -0.0637 & -0.159 \\
\hline
\end{tabular}




$\begin{array}{lcccc} & (1.178 \mathrm{e}+06) & (985,885) & (0.421) & (0.382) \\ \text { Quart_Djamona } & 5.124 \mathrm{e}+06^{*} & 4.940 \mathrm{e}+06^{* *} & 1.744^{* * *} & 1.694^{* * *} \\ & (2.895 \mathrm{e}+06) & (2.372 \mathrm{e}+06) & (0.556) & (0.211) \\ \text { Quart_Dadigou } & 2.630 \mathrm{e}+06 & 2.866 \mathrm{e}+06^{* * *} & 1.002^{* *} & 1.071^{* * *} \\ & (1.711 \mathrm{e}+06) & (832,840) & (0.391) & (0.346) \\ \text { Quart_Konkoare } & 1.910 \mathrm{e}+06^{* * *} & 2.167 \mathrm{e}+06^{* *} & 1.023^{* * *} & 1.098^{* * *} \\ & (652,814) & (949,109) & (0.190) & (0.180) \\ \text { Quart_Boumong } & 707,329 & 699,601 & 0.649 * * * & 0.662 \\ & (1.297 \mathrm{e}+06) & (544,647) & (0.180) & (0.473) \\ \text { Quart_Worgou } & 1.232 \mathrm{e}+06 & 1.183 \mathrm{e}+06 & 0.877 & 0.822^{* *} \\ & (1.631 \mathrm{e}+06) & (773,603) & (0.550) & (0.412) \\ \text { Quart_Dapankpergo } & -1.297 \mathrm{e}+06 & -1.544 \mathrm{e}+06 & -0.165 & -0.274 \\ \text { u } & & & & \\ & (1.456 \mathrm{e}+06) & (1.314 \mathrm{e}+06) & (0.504) & (0.363) \\ \text { Quart_Badoré } & 3.168 \mathrm{e}+06^{* * *} & 3.569 \mathrm{e}+06^{* * *} & 1.357^{* * *} & 1.471^{* *} \\ & (635,357) & (1.049 \mathrm{e}+06) & (0.361) & (0.615) \\ \text { Quart_Kombondjont } & 3.540 \mathrm{e}+06^{* *} & 3.510 \mathrm{e}+06^{* *} & 1.374 * * * & 1.375^{* *} \\ \text { e } & & & & \\ & (1.800 \mathrm{e}+06) & (1.512 \mathrm{e}+06) & (0.486) & (0.671) \\ \text { Constant } & -9.536 \mathrm{e}+06^{* *} & -1.112 \mathrm{e}+07^{* * *} & 10.25^{* * *} & 9.702^{* * *} \\ & (4.207 \mathrm{e}+06) & (4.212 \mathrm{e}+06) & (2.258) & (1.442) \\ & & 97 & 97 & 97 \\ \text { Observations } & 97 & 0.878 & 0.666 & 0.681 \\ \text { R-squared } & 0.871 & & & \end{array}$

